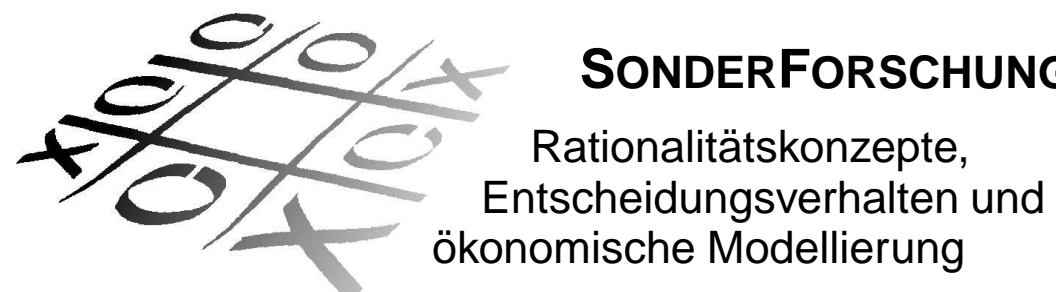

No. 03-29

\title{
Security And Potential Level Preferences With
} Thresholds

\author{
Ulrich Schmidt* \\ and Alexander Zimper**
}

October 2003

The authors want to thank Martin Hellwig, Peter Wakker, Ithzak Gilboa, Craig Fox, Martin Peterson, and Lennart Sjöberg for their suggestions and comments. Financial support of the second author by Deutsche Forschungsgemeinschaft via the Graduiertenkolleg îAllokation auf Finanz- und G uternärktenî, University of Mannheim, and by the Marie-Curie-program of the European Union is gratefully acknowledged.

*Lehrstuhl Finanzmarkttheorie, University of Hannover, email: U.Schmidt@mbox.vwl.uni-hannover.de

**Sonderforschungsbereich 504, email: zimper@bigfoot.com

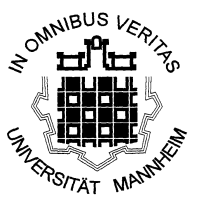

Universität Mannheim

$\mathrm{L} 13,15$

68131 Mannheim 


\title{
Security And Potential Level Preferences With Thresholds*
}

\author{
Ulrich Schmidt ${ }^{\dagger} \quad$ Alexander Zimper ${ }^{\ddagger}$
}

December 2003

\begin{abstract}
The security level models of Gilboa (1988) and of Jaffray (1988) as well as the security and potential level model of Cohen (1992) accommodate succesfully classical Allais paradoxa while they offer an interesting explanation for their occurrence. However, experimental data suggest a systematic violation of these models when lotteries with low probabilities of bad or good outcomes are involved. The present paper develops an axiomatic model that allows for thresholds in the perception of security and potential levels. The derived representation of preferences accomodates the observed violations of the original security and potential level models and provides a natural explanation for their occurence. Additionally, a more fundamental problem of the original models is resolved.
\end{abstract}

Keywords: Allais paradoxa, Security Level, Potential Level, Thresholds JEL Classification Number: D81

\footnotetext{
*The authors want to thank Martin Hellwig, Peter Wakker, Ithzak Gilboa, Craig Fox, Martin Peterson, and Lennart Sjöberg for their suggestions and comments. Financial support of the second author by Deutsche Forschungsgemeinschaft via the Graduiertenkolleg "Allokation auf Finanz- und Gütermärkten", University of Mannheim, and by the Marie-Curie-program of the European Union is gratefully acknowledged.

${ }^{\dagger}$ Corresponding author: Ulrich Schmidt, Lehrstuhl für Finanzmarkttheorie, University of Hannover, Königsworther Platz 1, 30167 Hannover, Germany. Email: u.schmidt@mbox.vwl.uni-hannover.de

${ }_{\ddagger}^{\ddagger}$ Sonderforschungsbereich 504, University of Mannheim, L13, 15, 68131 Mannheim, Germany. Email: zimper@bigfoot.com
} 


\section{Introduction}

In a well-known study on the psychology of decision making under risk, Lopes (1987) concluded that a decision maker takes into account three different factors while evaluating lotteries: What is the expected utility of this lottery? What is the worst outcome I can end up with by choosing this lottery (i.e. what is the security level of this lottery)? What is the best outcome I can end up with (i.e. what is the potential level)? This conclusion motivated Cohen (1992) to develop a three-criteria decision model which generalizes expected utility by allowing for security level and potential level considerations. An extension of this model has been provided by Essid (1997). Earlier models of Gilboa (1988) and Jaffray (1988) are very similar to Cohen's model but restrict attention to the security level alone. All three approaches explain Allais paradoxa by discontinuities of preferences resulting from the different security and potential levels of the lotteries involved. More recently, Cahteauneuf et al. (2003), building upon earlier work of Dow and Werlang (1994) and Eichberger and Kelsey (1999), have integrated Cohen's ideas in a model of decision making under uncertainty.

The accommodation of Allais paradoxa by the security level and potential level (SLPL) models is in our view intuitively very appealing. However, SL-PL models exhibit two major problems. First, they perform descriptively rather poorly when they are confronted with experimental data that go beyond the classical Allais paradoxa. A second and somewhat more fundamental problem can be characterized as follows: in real life there is always an (arbitrarily) small chance of immediate death and also a tiny chance of finding a suitcase on the street containing a huge cash amount of say ten billion dollars. Thus, it may be argued that in all decision problems death is always the security level while the amount of ten billion dollars is the potential level. If the security and potential levels are, however, identical in all lotteries, SL-PL models simply reduce to expected utility.

This second problem indicates that the shortcoming of SL-PL models is not so much owed to their assumption of security and potential considerations in general but rather to their assumption that security and potential considerations refer exclusively to the worst, respectively best, outcome in the support of a lottery, regardless of how small their probability actually is. This motivated us to develop an axiomatic model which extends existing SL-PL models by so-called thresholds such that security or potential considerations become only relevant if the probabilities of bad, respectively good, outcomes are not below some perceptual threshold level. For example, a lottery may be still perceived as very secure as long as bad outcomes realize with very small probability. Accordingly, a lottery may be associated with a low potential when the probability of a high outcome is only small for this lottery. It turns out that the introduction of threshold 
also resolves the first problem: as shown below, the poor descriptive performance of the original SL-PL models can be significantly improved by the introduction of thresholds.

Empirical observations that people often neglect very small probabilities (cf. Sjöberg (1999), (2000) and Stone, Yates, and Parker (1994)) can be regarded as further evidence in favor of thresholds: if the worst (respectively best) outcome has a very small probability, it seems unreasonable that people attach psychological importance to this outcome by regarding it as security (respectively potential) level and, at the same time, neglect its probability.

An analogous concept to our notion of thresholds can be seen in the Value-at-Risk (VaR) which is defined as the worst loss for a given confidence level (mostly 99\%). More precisely, for a confidence level of $99 \%$ the VaR of a lottery equals $x$ if the cumulative probability of outcomes smaller than $x$ is given by $1 \%$. The VaR has recently become very popular as a risk measure and it seems reasonable to consider the VaR as security level which is perfectly consistent with our model but not compatible with the original SL-PL models.

A further characteristic of our model is that it assumes a weaker version of independence than in the original SL-PL models: the risk-attitudes of a decision maker may depend in our model also on security and potential considerations. For example, our model allows for the possibility that decision makers are less risk averse for choice between insecure lotteries than for choice between secure lotteries. This is not the case for the original SL-PL models: because the utility functions for different security and potential levels differ in these models only by affine transformations, the risk attitudes are the same accross different security and potial levels.

The introduction of thresholds appears to us as a natural extension of SL-PL models, and, together with our weakened version of the independence axiom, it can successfully explain the most persistent choice patterns that are inconsistent with the original SL-PL models. Thus, as the main contribution of this paper, we demonstrate that the security and potential considerations of SL-PL models can go along with descriptive power under the intuitively appealing assumptions that the perception of security and of potential may depend on thresholds and that the risk attitudes of decision makers may depend on the security and potential levels involved.

The paper proceeds as follows. The next section introduces the original SL-PL models and presents the typical experimental designs in which violations of these models have been observed. Section 3 introduces our proposal for a partition of a set of lotteries into subsets of different security and potential levels with respect to thresholds. In section 4 we introduce our axioms and state two representation theorems: the first representation 
allows for violations of monotonicity with respect to first-order stochastic dominance whereas the second representation excludes such violations. In section 5 we demonstrate how the evidence against the original SL-PL models can be accommodated within our framework. All formal proofs are relegated to the appendix.

\section{The original SL-PL models}

In contrast to other alternatives to expected utility like models with the betweennessproperty or rank dependent utility models (see, e.g., Karni and Schmeidler (1991), Starmer (2000), and Schmidt (2003) for surveys), SL-PL models presume that discontinuities in the preferences describe best what is psychologically happening when decision makers commit Allais paradoxa: as an extension to expected utility security and potential factors may lead to jumps in the preferences such that a secure (respectively high potential) lottery dominates now all insecure (respectively low potential) lotteries that are sufficiently close in the sense of some mathematically defined neighborhood.

Let $x$ and $y$ denote the worst and best outcomes of the lottery $\sigma$. Then the utility of a lottery $\sigma$ is in Cohen's model given by

$$
V(\sigma)=a(x, y) * E U(\sigma)+b(x, y),
$$

where $E U(\sigma)$ denotes the standard expected utility of $\sigma$ and $a(x, y)$ and $b(x, y)$ are constants depending on the given security and potential level of $\sigma$. The models of Gilboa (1988) and Jaffray (1988) are similar but restrict attention to the security level $x$.

In the following we present experimental data of Sopher and Gigliotti (1993) and Chew and Waller (1986), which demonstrate that a majority of decision makers violates the SL-PL models in a very systematic way despite the fact that these models deal successfully with classical Allais paradoxa.

Problem 1. Consider the following three pairs of lotteries where, e.g., $(\$ 1 M \cdot 1)$ denotes a lottery that gives $\$ 1$ Mill. with probability one:

$$
\begin{array}{ll}
S 1=(\$ 1 M \cdot 1) & R 1=(\$ 0 \cdot 0.01 \oplus \$ 1 M \cdot 0.89 \oplus \$ 5 M \cdot 0.10) \\
S 2=(\$ 0 \cdot 0.89 \oplus \$ 1 M \cdot 0.11 \oplus \$ 5 M \cdot 0) & R 2=(\$ 0 \cdot 0.9 \oplus \$ 1 M \cdot 0 \oplus \$ 5 M \cdot 0.10) \\
S 3=(\$ 0 \cdot 0 \oplus \$ 1 M \cdot 0.11 \oplus \$ 5 M \cdot 0.89) & R 3=(\$ 0 \cdot 0.01 \oplus \$ 1 M \cdot 0 \oplus \$ 5 M \cdot 0.99)
\end{array}
$$

A decision maker with the choice pattern $(S 1, R 2)$, i.e., preferring $S 1$ to $R 1$ and preferring $R 2$ to $S 2$, commits the classical Allais paradox. The existing SL-PL models can accommodate this Allais paradox via the security effect: At first a decision maker 
prefers the secure lottery $S 1$ to the insecure lottery $R 1$ because by the security effect her evaluation of lotteries experiences an upward-jump when the probability of the bad outcome $\$ 0$ drops to zero. However, after substituting the bad outcome $\$ 0$ for the outcome $\$ 1 M$ with probability weigt 0.89 in the lotteries $S 1$ and $R 1$ there is no longer any security effect when the resulting lotteries $S 2$ and $R 2$ are compared and as a consequence $R 2$ may now become preferred to $S 2$ as observed in the Allais paradox.

\section{INSERT FIGURE 1 ABOUT HERE}

However, the occurrence of this security effect implies for the original SL-PL models that the decision maker must prefer $S 3$ to $R 3$ (see figure 1). Sopher and Gigliotti (1993) have elicited preferences for these three choice pairs and according to their results 45 individuals have chosen $(S 1, R 2, S 3)$ whereas 58 individuals have chosen $(S 1, R 2, R 3)$. That is, the majority of decision makers who commit this classical Allais paradox have displayed preferences that are not compatible with existing SL-PL models.

Problem 2. Consider now the following three pairs of lotteries

$$
\begin{array}{ll}
Q 1=(\$ 40 \cdot 1) & T 1=(\$ 0 \cdot 0.5 \oplus \$ 100 \cdot 0.5) \\
Q 2=(\$ 40 \cdot 1) & T 2=(\$ 0 \cdot 0.05 \oplus \$ 40 \cdot 0.90 \oplus \$ 100 \cdot 0.05) \\
Q 3=(\$ 0 \cdot 0.9 \oplus \$ 40 \cdot 0.10) & T 3=(\$ 0 \cdot 0.95 \oplus \$ 100 \cdot 0.05)
\end{array}
$$

A decision maker with the choice pattern $(Q 1, T 2)$ commits another classical Allais paradox that is typically observed for moderate payoffs or losses. This choice behavior can not be accommodated by the security level models of Gilboa (1988) and Jaffray (1988), however, it is possible to accommodate this choice behavior within Cohen's model by a potential effect.

\section{INSERT FIGURE 2 ABOUT HERE}

The assumption of this potential effect implies in Cohen's model that the decision maker prefers also Q3 to T3 (see figure 2). But Chew and Waller's (1986) experimental data display this choice pattern $(Q 1, T 2, Q 3)$ only for 12 individuals whereas the choice pattern $(Q 1, T 2, T 3)$ appears for 28 individuals. Again the vast majority of decision makers who commit a classical Allais paradox violate preferences that are admissible for the existing SL-PL models. 
A closer examination of problem 1 and of problem 2 reveals that SL-PL models are violated when lotteries become involved such that bad outcomes or good outcomes realize with rather small probability. We think therefore that the key for solving these systematic violations of SL-PL models is a departure from the assumption that a lottery is not secure, or is a high potential lottery, just because bad, respectively good, outcomes realize with positive probability. In contrast, our SL-PL model with thresholds, will allow to perceive lotteries as secure (of low potential) when the bad (good) outcomes realize only with sufficiently small probabilities.

\section{Security and Potential Levels with Thresholds}

The objective for our particular formalism of thresholds has been twofold. First, we wanted to keep the model as simple as possible. As a consequence we introduce only two new parameters to the original SL-PL models, a threshold for security levels and a threshold for potential levels, whereby the security level and the potential level of a lottery is then easily determined by its cumulative distribution function. More sophisticated SL-PL models with thresholds could be constructed, however, we are willingly trading off richness of the model for a simple formalism that captures well the basic idea. Secondly, we introduce a formalism of thresholds such that the resulting preferences will not necessarily violate monotonicity with respect to first-order stochastic dominance (FOSD). The original SL-PL models do not violate this fundamental requirement for rational decision makers, however, one can easily construct proposals for thresholds for which the discontinuous preferences of SL-PL models lead to violations of monotonicity with respect to FOSD.

Let $X=\left\{x_{1}, \ldots, x_{n}\right\}$ denote a finite set of totally ordered deterministic outcomes with $x_{1}<\ldots<x_{n}$, and let $\triangle(X)$ denote the set of all probability distributions, i.e., lotteries, over $X$. A lottery $\sigma \in \triangle(X)$ is also written as $\left(\sigma_{1} \cdot x_{1} \oplus \ldots \oplus \sigma_{n} \cdot x_{n}\right)$ where $\sigma_{k}$ denotes the probability by which outcome $x_{k}$ realizes. Let $F[\sigma]\left(x_{k}\right)$ denote the cumulative distribution function of lottery $\sigma$ evaluated at outcome $x_{k}$. For so-called thresholds $\varepsilon, \eta \in[0,1)$ denote by $\Pi(\varepsilon, \eta)$ a collection of sets

$$
\Pi(\varepsilon, \eta)=\left\{\triangle\left(x_{j}, x_{k}\right)\right\}_{j=1, \ldots, n ; k \geq j}
$$

such that

$\sigma \in \triangle\left(x_{j}, x_{k}\right)$ iff $F[\sigma]\left(x_{j-1}\right) \leq \varepsilon, F[\sigma]\left(x_{j}\right)>\varepsilon$ AND $1-F[\sigma]\left(x_{k}\right) \leq \eta, 1-F[\sigma]\left(x_{k-1}\right)>\eta$ 
Observation: $\Pi(\varepsilon, \eta)$ is a partition of $\triangle(X)$ with convex cells $\triangle(x, y) \in \Pi(\varepsilon, \eta)$. Moreover, for $\varepsilon+\eta<1$ these cells are non-empty.

We say a lottery $\sigma \in \triangle(x, y)$, with $\triangle(x, y) \in \Pi(\varepsilon, \eta)$, has security level $x$ and potential level $y$. The threshold-value $\varepsilon$ for security levels guarantees that worse outcomes than $x$ can realize for a lottery of security level $x$ at most with probability $\varepsilon$. Accordingly, better outcomes than $y$ can realize for a lottery of potential level $y$ at most with probability $\eta$. For $\varepsilon, \eta=0$ the partition $\Pi(\varepsilon, \eta)$ reduces to the original SL-PL partition of Cohen (1992) where the security level of a lottery is the worst outcome in its support and the potential level is the best outcome in the support, i.e., $\sigma \in \triangle(x, y)$ if and only if $x=\min \operatorname{Support}(\sigma)$ and $y=\max \operatorname{Support}(\sigma)$.

\section{Axiomatic Analysis}

Existing axiomatizations of SL-PL models presume basically that the axioms of expected utility theory remain valid within security and potential level subsets whereas the independence axiom and continuity may be violated while passing from one subset to another. However, some weakened version of the independence axiom and of the Archimedean axiom have to be satisfied between different subsets in order to obtain a simple real-valued utility representation. Apart from introducing threshold our axiomatization differs from Cohen's (1992) model by imposing only a weakened variant of her independence axiom. As a consequence of this weakening we can accommodate indifference curves with different slopes on different SL-PL subsets such that there may be different risk attitudes within different SL-PL subsets. We employ the following three axioms:

A1-Ordering: Asymmetry, Transitivity and Completeness of the strict preference relation $\succ$ on $\triangle(X)$.

A2-Subset Dependent Archimedean Axiom: Suppose $\sigma \in \triangle(x, y)$ and $\rho, \tau \in$ $\triangle\left(x^{\prime}, y^{\prime}\right)$ for $\triangle(x, y), \triangle\left(x^{\prime}, y^{\prime}\right) \in \Pi(\varepsilon, \eta)$. If $\tau \succ \sigma \succ \rho$ then

$$
\lambda \cdot \tau \oplus(1-\lambda) \cdot \rho \sim \sigma
$$

for a unique $\lambda \in(0,1)$. 
A3-Subset Dependent Independence Axiom: Suppose $\triangle(x, y), \triangle\left(x^{\prime}, y^{\prime}\right) \in$ $\Pi(\varepsilon, \eta)$. If there exist lotteries $\sigma, \tau \in \triangle(x, y)$ and lotteries $\sigma^{\prime}, \tau^{\prime} \in \triangle\left(x^{\prime}, y^{\prime}\right)$ such that $\sigma \succ(\sim) \sigma^{\prime}$ and $\tau \succeq(\sim) \tau^{\prime}$ then

$$
\lambda \cdot \sigma \oplus(1-\lambda) \cdot \tau \succ(\sim) \lambda \cdot \sigma^{\prime} \oplus(1-\lambda) \cdot \tau^{\prime}
$$

for all $\lambda \in(0,1)$.

We define now a subset-dependent expected utility functional $V: \triangle(X) \times \Pi(\varepsilon, \eta) \rightarrow$ $\mathbf{R}_{+}$by

$$
V(\sigma, \triangle(x, y))=\sum_{k=1}^{n} \sigma\left(x_{k}\right) * u\left(x_{k}, \triangle(x, y)\right)
$$

with $u: X \times \Pi(\varepsilon, \eta) \rightarrow \mathbf{R}_{+}$.

\section{Theorem 1:}

Let preferences on $\triangle(X)$ satisfy the axioms (A1)-(A3) for some partition $\Pi(\varepsilon, \eta)$ with $\varepsilon+\eta<1$. Then these preferences are representable by a utility function $U: \triangle(X) \rightarrow \mathbf{R}_{+}$ such that

$$
U(\sigma)=V(\sigma, \triangle(x, y))
$$

with $\sigma \in \triangle(x, y)$, whereby the function $V$ is defined in (1).

Conversely, any such $U$ represents preferences that fulfil the axioms (A1)-(A3).

The representation of Theorem 1 allows for preferences that may violate monotonicity w.r.t. FOSD. However, one main motivation for our particular definition of thresholds was the desire to introduce SL-PL partitions such that preferences may be consistent with FOSD as in the original SL-PL models. We will now derive a second representation theorem which will guarantee consistency with FOSD.

Recall the definition of first-order stochastic dominance: A lottery $\sigma$ dominates a lottery $\tau$ w.r.t. FOSD, i.e., $\sigma \succeq_{F O S D} \tau$, if and only if $F[\sigma](x) \leq F[\tau](x)$ for all $x \in X$. Moreover, if additionally $F[\sigma](x)<F[\tau](x)$ for some $x \in X$ we say that $\sigma$ dominates a lottery $\tau$ strictly w.r.t. FOSD and we write then $\sigma \succ_{F O S D} \tau$. Verify the following two properties of $\succ_{F O S D}$ that will be exploited later on in the proof of the second representation theorem:

Continuity: Suppose $\left(\sigma_{k}\right)_{k \in \mathbf{N}}$ with $\lim _{k \rightarrow \infty} \sigma_{k}=\sigma$. If there is a $\tau$ such that $\tau \succ_{F O S D}$ $\sigma_{k}$ for all $k \in \mathbf{N}$ then $\tau \succeq_{F O S D} \sigma$.

Quasiconcavity: If $\tau \succ_{F O S D} \sigma$ then $\lambda \cdot \tau \oplus(1-\lambda) \cdot \sigma \succ_{F O S D} \sigma$ for all $\lambda \in(0,1)$. 
Consistency of preferences with FOSD is guaranteed by the following condition:

A4-Monotonicity with respect to FOSD: If $\sigma \succeq_{F O S D} \tau$ then $\sigma \succeq \tau$; and if $\sigma \succ_{F O S D} \tau$ then $\sigma \succ \tau$.

Adding (A4) to the axiomatic system of Theorem 1 leads to the second representation theorem.

\section{Theorem 2:}

Let preferences on $\triangle(X)$ satisfy the axioms (A1)-(A4) for some partition $\Pi(\varepsilon, \eta)$ with $\varepsilon+\eta<1$. Then these preferences are representable by a utility function $U: \triangle(X) \rightarrow \mathbf{R}_{+}$ such that

$$
U(\sigma)=V(\sigma, \triangle(x, y))
$$

for $\sigma \in \triangle(x, y)$, whereby the function $V$ defined in (1) has the following properties

(i) for all $\triangle(x, y) \in \Pi(\varepsilon, \eta)$

$$
u\left(x_{m}, \triangle(x, y)\right)<u\left(x_{m+1}, \triangle(x, y)\right)
$$

with $1 \leq m \leq n-1$,

(ii)

$$
\lim _{k \rightarrow \infty} V\left(\sigma_{k}, \triangle(x, y)\right) \leq V(\sigma, \triangle(\bar{x}, \bar{y}))
$$

for any sequence $\left(\sigma_{k}\right)_{k \in \mathbf{N}}$ with $\lim _{k \rightarrow \infty} \sigma_{k}=\sigma, \sigma_{k} \in \triangle(x, y)$ for all $k \in N$, and $\sigma \in \triangle(\bar{x}, \bar{y})$ with $\bar{x} \geq x, \bar{y} \geq y$,

(iii)

$$
V(\sigma, \triangle(x, y)) \leq \lim _{k \rightarrow \infty} V\left(\sigma_{k}, \triangle(\bar{x}, \bar{y})\right)
$$

for any sequence $\left(\sigma_{k}\right)_{k \in \mathbf{N}}$ with $\lim _{k \rightarrow \infty} \sigma_{k}=\sigma, \sigma_{k} \in \triangle(\bar{x}, \bar{y})$ for all $k \in N$, and $\sigma \in \triangle(x, y)$ with $\bar{x} \geq x, \bar{y} \geq y$.

Conversely, any such $U$ represents preferences that fulfil the axioms (A1)-(A4).

For arbitrary functions $V(\cdot, \triangle(x, y))$ and $V(\cdot, \triangle(\bar{x}, \bar{y}))$ it may not be obvious whether the conditions (4) and (5) are satisfied, or not. But observe that (4) and (5) are trivially fulfilled for vNM-utility indices $u\left(x_{k}, \cdot\right)$ that are monotonic on $\Pi(\varepsilon, \eta)$ for all $x_{k} \in X$. As a consequence we can immediately derive the following corollary: 


\section{Corollary 1:}

Any utility function $U: \triangle(X) \rightarrow R_{+}$with

$$
U(\sigma)=V(\sigma, \triangle(x, y))
$$

for $\sigma \in \triangle(x, y)$, with $V$ defined in (1), is representing preferences that fulfil the axioms (A1)-(A4) if we have for all $x_{k} \in X$

$$
u\left(x_{k}, \triangle(x, y)\right) \leq u\left(x_{k}, \triangle(\bar{x}, \bar{y})\right)
$$

with $\bar{x} \geq x, \bar{y} \geq y$.

\section{Accommodating the Experimental Evidence}

Our formalism of thresholds presented in section 3 is clearly a very idealizing concept and, therefore, it seems unreasonable that this concept can capture all empirical choice patterns which may be associated with the existence of thresholds in a decisionmaker's evaluation of lotteries. We have focused on our simple concept of a SL-PL partition, with only two parameters more than Cohen's original SL-PL partition, because we wanted to obtain a model which is as simple as possible while it can solve the two major problems concerning the original SL-PL models mentioned in the introduction.

It remains to show that our model of SL-PL preferences with thresholds can indeed accommodate the observed choice patterns of the two problems presented in section 2 which violate the original SL-PL models. In the following analysis, the employed utility values fulfil the assumptions of the Corollary 1 such that monotonicity with respect to first-order stochastic dominance is satisfied.

Problem 1. (See figure 3) Consider the following specification of the utility function for a SL-PL partition $\Pi(\varepsilon, \eta)$, with $\varepsilon=0.01$ and $\eta=0$ :

For security level $\$ 1 M$

$$
\begin{aligned}
u(\$ 0, \triangle(\$ 1 M, y)) & =0 \text { for } \$ 1 M \leq y \leq \$ 5 M \\
u(\$ 1 M, \triangle(\$ 1 M, y)) & =0.99 \text { for } \$ 1 M \leq y \leq \$ 5 M \\
u(\$ 5 M, \triangle(\$ 1 M, y)) & =1 \text { for } \$ 1 M \leq y \leq \$ 5 M
\end{aligned}
$$

For security level $\$ 0$

$$
\begin{aligned}
u(\$ 0, \triangle(\$ 0, y)) & =0 \text { for } \$ 0 \leq y \leq \$ 5 M \\
u(\$ 1 M, \triangle(\$ 0, y)) & =(0.99)^{100} \text { for } \$ 0 \leq y \leq \$ 5 M \\
u(\$ 5 M, \triangle(\$ 0, y)) & =1 \text { for } \$ 0 \leq y \leq \$ 5 M
\end{aligned}
$$


For security level $\$ 5 M$

$$
\begin{aligned}
u(\$ 0, \triangle(\$ 5 M, y)) & =0 \text { for } y=\$ 5 M \\
u(\$ 1 M, \triangle(\$ 5 M, y)) & =1.98 \text { for } y=\$ 5 M \\
u(\$ 5 M, \triangle(\$ 5 M, y)) & =2 \text { for } y=\$ 5 M
\end{aligned}
$$

When we compute now the utility numbers for the lotteries in problem 1 we obtain the desired choice pattern $(S 1, R 2, R 3)$

$$
\begin{aligned}
U(S 1)= & V(S 1, \triangle(\$ 1 M, \$ 1 M))=0.99 \\
> & 0.9811=V(R 1, \triangle(\$ 1 M, \$ 1 M))=U(R 1) \\
U(S 2)= & V(S 2, \triangle(\$ 0, \$ 1 M))=0.04 \\
& <0.1=V(R 2, \triangle(\$ 0, \$ 1 M))=U(R 2) \\
U(S 3)= & V(S 3, \triangle(\$ 1 M, \$ 5 M))=0.999 \\
< & 1.98=V(R 3, \triangle(\$ 5 M, \$ 5 M))=U(R 3)
\end{aligned}
$$

\section{INSERT FIGURE 3 ABOUT HERE}

Problem 2. (See figure 4) Consider the following specification of the utility function for a SL-PL partition $\Pi(\varepsilon, \eta)$, with $\varepsilon=0.05$ and $\eta=0$ :

For security level $\$ 0$

$$
\begin{aligned}
u(\$ 0, \triangle(\$ 0, y)) & =0 \text { for } \$ 0 \leq y \leq \$ 100 M \\
u(\$ 40, \triangle(\$ 0, y)) & =0.4 \text { for } \$ 0 \leq y \leq \$ 100 M \\
u(\$ 100, \triangle(\$ 0 M, y)) & =1 \text { for } \$ 0 \leq y \leq \$ 100 M
\end{aligned}
$$

For security levels $\$ 40$ and $\$ 100$

$$
\begin{aligned}
u(\$ 0, \triangle(x, y)) & =1 \text { for } \$ 40 \leq x \leq y \leq \$ 100 \\
u(\$ 40, \triangle(x, y)) & =1.4 \text { for } \$ 40 \leq x \leq y \leq \$ 100 \\
u(\$ 100, \triangle(x, y)) & =2 \text { for } \$ 40 \leq x \leq y \leq \$ 100
\end{aligned}
$$


Computing then the utility numbers for the lotteries in problem 2 gives the desired choice pattern $(Q 1, T 2, T 3)$

$$
\begin{aligned}
U(Q 1) & =V(Q 1, \triangle(\$ 40, \$ 40))=1.4 \\
& >0.2=V(T 1, \triangle(\$ 0, \$ 100))=U(T 1) \\
U(Q 2) & =V(Q 2, \triangle(\$ 40, \$ 40))=1.4 \\
& <1.41=V(T 2, \triangle(\$ 40, \$ 40))=U(R 2) \\
U(Q 3) & =V(Q 3, \triangle(\$ 0, \$ 40))=0.04 \\
& <0.05=V(T 3, \triangle(\$ 0, \$ 40))=U(T 3)
\end{aligned}
$$

\section{INSERT FIGURE 4 ABOUT HERE}

Remark 1. Compared to the original SL-PL models the accommodation of the choice pattern $(Q 1, T 2, T 3)$ in problem 2 requires only a positive threshold-value whereas the accommodation of $(S 1, R 2, R 3)$ in problem 1 requires additionally our weakened version of the independence axiom: When the slopes of the indifference curves are the same across different SL-PL subsets (as implied by the original SL-PL models) we could not have $(S 1, R 2)$ because the lotteries $S 1, R 1$, on the one hand, and the lotteries $S 2, R 2$, on the other hand, have in our SL-PL partition the same security and potential levels. Thus, if we assumed the independence axiom of the original SL-PL models for our SLPL partition then $S 1$ is preferred to $R 1$ if and only if $S 2$ is preferred to $R 2$. Observe that the subset-dependent expected utility functional $V(\cdot, \triangle(\$ 0, y))$ results from a convex transformation of the subset-dependent expected utility functional $V(\cdot, \triangle(\$ 1 M, y))$ which implies steeper slopes of the indifference curves on SL-PL subsets with higher security levels. In analogy to the comparison of risk attitudes within the expected utility framework we could say that the decision maker of our representation makes riskier choices when she has to decide between low-security lotteries as when she has to decide between high-security lotteries. In our opinion such security and potential level dependent risk-attitudes can make some intuitive sense and they could be justified, e.g., by

the following rationale: If I feel that there are only insecure alternatives I can choose from, then I might go as well for riskier alternatives. 
Remark 2. Although the choice pattern $(Q 1, T 2)$ violates the original security level models of Gilboa (1988) and of Jaffray (1988) it can be accommodated within Cohen's SL-PL model under the assumption of a potential effect (which had actually been introduced by Cohen (1992) for accommodating typical violations of expected utility preferences when losses are considered as outcomes). However, it can be easily shown that the occurrence of a potential effect implies then also $Q 3 \succ T 3$ in Cohen's model (compare figure 2). In contrast, our model can explain $(Q 1, T 2, T 3)$ by the occurrence of a security effect under the assumption that the lottery $T 2$ is considered as comparably safe. That is, the 0.05 chance of ending up with the bad outcome of $\$ 0$ does not bother here the decision maker that much as to let her evaluation of this lottery be affected by security consideration with respect to the secure lottery $Q 2$.

Remark 3. Motivated by the discussion whether Allais paradoxa are persistently committed within the interior of the Marschak-Machina triangle, or not, Harless and Camerer (1994) conclude after a broad statistical investigation of experiments: "The conjecture that EU violations disappear in the interior appears to be false." The original SL-PL models can not take account of Allais paradoxa that are committed within the interior of the Marschak-Machina triangle, however, the introduction of thresholds implies obviously violations of EU-theory within the interior of the Marschak-Machina triangles that may follow quite complex patterns according to the specification of threshold values.

\section{Appendix: Proofs}

Proof of the observation: Convexity of each SL-PL subset $\triangle(x, y)$ is obviously implied by the definition of the cumulative distribution function. By the same argument we see immediately that $\Pi(\varepsilon, \eta)$ is a partition of $\triangle(X)$ regardless of the values of $\varepsilon$ and $\eta$ :

i.) $\triangle(x, y) \cap \triangle\left(x^{\prime}, y^{\prime}\right)=\emptyset$ for $\triangle(x, y) \neq \triangle\left(x^{\prime}, y^{\prime}\right)$ and

ii.)

$$
\bigcup_{\{(x, y) \in X \times X \mid x \leq y\}} \triangle(x, y)=\triangle(X)
$$

It remains to show that each is SL-PL subset $\triangle(x, y)$ is non-empty if $\varepsilon+\eta<1$. Just observe that there exists always the lottery

$$
\left(\varepsilon+\frac{1-\eta-\varepsilon}{2}\right) \cdot x \oplus\left(\eta+\frac{1-\eta-\varepsilon}{2}\right) \cdot y \in \triangle(x, y)
$$

for $\varepsilon+\eta<1$. 


\section{Proof of the Representation Theorems}

We proceed by proving in detail the second representation theorem whose proof is more demanding than the proof of the first representation theorem because the preferences must satisfy here additionally the assumption of monotonicity w.r.t. FOSD. We will omitt an explicit proof of the first representation theorem because such a proof coincides basically with our proof of the second representation theorem when we simply do not take account of the restrictions required by monotonicity w.r.t. FOSD.

Part A. We demonstrate that all preferences on $\triangle(x, y)$ fulfilling (A1)-(A4) must be representable by $(2)$ such that for all $\triangle(x, y) \in \Pi(\varepsilon, \eta)$ the $V(\cdot, \triangle(x, y))$ are subsetdependent EU-functionals as defined in (1).

Recall that the assumption of (A1)-(A4) implies that preferences over lotteries within the same SL-PL subset can be represented by some EU-functional; i.e., for $\sigma, \tau \in \triangle(x, y)$ we have $\sigma \succ \tau$ iff

$$
\sum_{k=1}^{n} \sigma\left(x_{k}\right) * u\left(x_{k}, \triangle(x, y)\right)>\sum_{k=1}^{n} \tau\left(x_{k}\right) * u\left(x_{k}, \triangle(x, y)\right)
$$

for strictly monotonic $u(\cdot, \triangle(x, y))$. This is by definition equivalent to

$$
V(\sigma, \triangle(x, y))>V(\tau, \triangle(x, y))
$$

Presume from now on that the preferences over the lotteries within any SL-PL subset $\triangle(x, y) \in \Pi(\varepsilon, \eta)$ are represented by some expected utility function $V(\cdot, \triangle(x, y))$. Observe that by construction of $\Pi(\varepsilon, \eta)$ and by application of (A2) and (A4)

$$
\begin{aligned}
& \inf _{\sigma \in \triangle(x, y)} V(\sigma, \triangle(x, y))=V\left(\varepsilon \cdot x_{1} \oplus(1-\varepsilon-\eta) \cdot x \oplus \eta \cdot y, \triangle(x, y)\right) \\
& \sup _{\sigma \in \triangle(x, y)} V(\sigma, \triangle(x, y))=V\left(\varepsilon \cdot x \oplus(1-\varepsilon-\eta) \cdot y \oplus \eta \cdot x_{n}, \triangle(x, y)\right)
\end{aligned}
$$

and let us introduce the following notational conventions for these particular lotteries

$$
\begin{aligned}
\inf \triangle(x, y) & =\varepsilon \cdot x_{1} \oplus(1-\varepsilon-\eta) \cdot x \oplus \eta \cdot y \\
\sup \triangle(x, y) & =\varepsilon \cdot x \oplus(1-\varepsilon-\eta) \cdot y \oplus \eta \cdot x_{n}
\end{aligned}
$$

The EU-representation $V(\cdot, \triangle(x, y))$ of preferences within $\triangle(x, y)$ implies then that there exists for every $\sigma \in \triangle(x, y)$ a unique $\nu_{\sigma} \in[0,1]$ such that

$$
\begin{aligned}
V(\sigma, \triangle(x, y)) & =V\left(\nu_{\sigma} \cdot \inf \triangle(x, y) \oplus\left(1-\nu_{\sigma}\right) \cdot \sup \triangle(x, y), \triangle(x, y)\right) \\
& =\nu_{\sigma} * V(\inf \triangle(x, y), \triangle(x, y))+\left(1-\nu_{\sigma}\right) * V(\sup \triangle(x, y), \triangle(x, y))
\end{aligned}
$$


Thus, for all preferences fulfilling (A1)-(A4) we can determine by (8) the utility numbers $V(\sigma, \triangle(x, y))$ for all lotteries $\sigma \in \triangle(x, y)$ w.r.t. the utility numbers

$$
V(\inf \triangle(x, y), \triangle(x, y)), V(\sup \triangle(x, y), \triangle(x, y))
$$

Verify now the following two properties of the lotteries (7):

(1)

$$
\begin{aligned}
\inf \triangle(x, y) & \in \triangle(x, x) \\
\sup \triangle(x, y) & \in \triangle(y, y)
\end{aligned}
$$

That is, inf $\triangle(x, y)$ and $\sup \triangle(x, y)$ are elements of $\triangle(x, y)$ if and only if $x=y$. Conversely, all SL-PL subsets $\triangle(x, y)$ with $x<y$ do neither contain a worst (preferenceminimizing) lottery inf $\triangle(x, y)$ nor a best (preference-maximizing) lottery $\sup \triangle(x, y)$.

(2) For any $\triangle(\bar{x}, \bar{y}) \in \Pi(\varepsilon, \eta)$, with $\bar{x} \geq x$ and $\bar{y} \geq y$

$$
\sup \triangle(\bar{x}, \bar{y}) \succ_{F O S D} \sigma
$$

for all $\sigma \in \triangle(x, y)$ with $\sigma \neq \sup \triangle(x, y)$, and

$$
\sigma^{\prime} \succ_{F O S D} \inf \triangle(x, y)
$$

for all $\sigma^{\prime} \in \triangle(\bar{x}, \bar{y})$ with $\sigma^{\prime} \neq \inf \triangle(\bar{x}, \bar{y})$. (Notice: this is in particular true for $\bar{x}=x$ and $\bar{y}=y$.)

Presume that $V(\sigma, \triangle(x, y))$ is given for all $\sigma \in \triangle(x, y)$. Furthermore, assume for now that we have also the utility-numbers (9). We are going to show in a first step that we can then choose for any arbitrary SL-PL subset $\triangle(\bar{x}, \bar{y}) \in \Pi(\varepsilon, \eta)$, with $\bar{x} \geq x$ and $\bar{y} \geq y$, some utility function $V(\cdot, \triangle(\bar{x}, \bar{y}))$ such that

$$
\sigma \succ(\sim) \sigma^{\prime} \Rightarrow V(\sigma, \triangle(x, y))>(=) V\left(\sigma^{\prime}, \triangle(\bar{x}, \bar{y})\right)
$$

for all $\sigma \in \triangle(x, y)$ and $\sigma^{\prime} \in \triangle(\bar{x}, \bar{y})$ whenever the preferences fulfil (A1)-(A4).

In a second step we demonstrate how the utility numbers

$$
\begin{aligned}
& V(\inf \triangle(x, y), \triangle(x, y)), V(\sup \triangle(x, y), \triangle(x, y)) \\
& V(\inf \triangle(\bar{x}, \bar{y}), \triangle(\bar{x}, \bar{y})), V(\sup \triangle(\bar{x}, \bar{y}), \triangle(\bar{x}, \bar{y}))
\end{aligned}
$$

can be derived for all $\triangle(x, y), \triangle(\bar{x}, \bar{y}) \in \Pi(\varepsilon, \eta)$ such that (10) is fulfilled for any preferences on $\triangle(X)$ satisfying (A1)-(A4). 
Step 1. Consider at first the case $\sigma^{\prime} \succ \sigma$ for all $\sigma \in \triangle(x, y)$ and $\sigma^{\prime} \in \triangle(\bar{x}, \bar{y})$. Let

$$
\begin{aligned}
\inf \triangle(\bar{x}, \bar{y}) & =\sup \triangle(x, y) \\
\sup \triangle(\bar{x}, \bar{y}) & =\inf \triangle(\bar{x}, \bar{y})+1
\end{aligned}
$$

whereby $V\left(\sigma^{\prime}, \triangle(\bar{x}, \bar{y})\right)$ is then determined for all $\sigma^{\prime} \in \triangle(\bar{x}, \bar{y})$ by (8). Obviously, (10) is satisfied.

Consider now the case that preferences overlap, i.e., there is a $\rho^{\prime} \in \triangle(\bar{x}, \bar{y})$ such that $\sigma \succeq \rho^{\prime}$ for some $\sigma \in \triangle(x, y)$. Observe at first that this is impossible whenever $\Pi(\varepsilon, \eta)$ is given such that

$$
\sup \triangle(x, y)=\inf \triangle(x, y)
$$

i.e., $\varepsilon=\eta$ and $x=y$. Then the first case would apply. But if

$$
\sup \triangle(x, y)>\inf \triangle(x, y)
$$

there must be some $\tau^{*} \in \triangle(x, y)$ and some $\sigma^{\prime} \in \triangle(\bar{x}, \bar{y})$ such that

$$
\tau^{*} \succ \sigma^{\prime} \succ \inf \triangle(x, y)
$$

Why? If $\sigma \succ \rho^{\prime}$ just let $\sigma^{\prime}=\rho^{\prime}$ and $\tau^{*}=\sigma$. If $\sigma \sim \rho^{\prime}$ and $\rho^{\prime} \neq \inf \triangle(\bar{x}, \bar{y})$ there is no worst lottery in $\triangle(\bar{x}, \bar{y})$ and there must be some $\sigma^{\prime} \in \triangle(\bar{x}, \bar{y})$ such that $\sigma \succ \sigma^{\prime}$ with $\tau^{*}=\sigma$. Moreover, by (A4) $\sigma^{\prime} \succ \inf \triangle(x, y)$. Notice: $\sigma \sim \rho^{\prime}$ and $\rho^{\prime}=\inf \triangle(\bar{x}, \bar{y})$ then $x<y$ by (A4). Just let $\sigma^{\prime}=\rho^{\prime}$ and observe that there must be some $\tau^{*} \in \triangle(x, y)$ such that $\tau^{*} \succ \sigma$ because by $x<y$ there is no best lottery in $\triangle(\bar{x}, \bar{y})$.

By (A2) there exists a unique $\lambda \in(0,1)$ such that

$$
\sigma^{\prime} \sim \lambda \cdot \tau^{*} \oplus(1-\lambda) \cdot \inf \triangle(x, y)=\sigma^{*}
$$

and we let

$$
V\left(\sigma^{\prime}, \triangle(\bar{x}, \bar{y})\right)=V\left(\sigma^{*}, \triangle(x, y)\right)
$$

If (13) is fulfilled there must also exist a $\tau^{\prime} \in \triangle(\bar{x}, \bar{y})$ such that

$$
\tau^{*} \sim \tau^{\prime} \succ \sigma^{\prime} \succ \inf \triangle(x, y)
$$

Why? By construction of $\Pi(\varepsilon, \eta)$ we have $\sup \triangle(\bar{x}, \bar{y}) \succ_{F O S D} \tau^{*}$ and by continuity of $\succ_{F O S D}$ we can find for each $\tau^{*} \in \triangle(x, y)$ some $\rho$ such that $\rho \succ \tau^{*}$ by (A4). By (A2)

$$
\tau^{*} \sim \mu \cdot \rho \oplus(1-\mu) \cdot \sigma^{\prime}=\tau^{\prime}
$$

for a unique $\mu \in(0,1)$. Let

$$
V\left(\tau^{\prime}, \triangle(\bar{x}, \bar{y})\right)=V\left(\tau^{*}, \triangle(x, y)\right)
$$


Observe now that for preferences satisfying (A3) we have

$$
\lambda \cdot \sigma^{\prime} \oplus(1-\lambda) \cdot \tau^{\prime} \sim \lambda \cdot \sigma^{*} \oplus(1-\lambda) \cdot \tau^{*}
$$

for $\lambda \in(0,1)$ which can obviously represented by (2) because

$$
\begin{aligned}
V\left(\lambda \cdot \sigma^{\prime} \oplus(1-\lambda) \cdot \tau^{\prime}, \triangle(\bar{x}, \bar{y})\right) & =\lambda * V\left(\sigma^{\prime}, \triangle(\bar{x}, \bar{y})\right)+(1-\lambda) * V\left(\tau^{\prime}, \triangle(\bar{x}, \bar{y}) \backslash 15\right) \\
& =\lambda * V\left(\sigma^{*}, \triangle(x, y)\right)+(1-\lambda) * V\left(\tau^{*}, \triangle(x, y)\right) \\
& =V\left(\lambda \cdot \sigma^{*} \oplus(1-\lambda) \cdot \tau^{*}, \triangle(x, y)\right)
\end{aligned}
$$

for $\lambda \in(0,1)$. Moreover, by transitivity we can then conclude that (10) is satisfied for all lotteries in $\triangle(x, y)$ and $\triangle(\bar{x}, \bar{y})$.

Step 2. In the following we are going to describe an effective procedure by which the utility numbers (11) could be derived for all $\triangle(x, y), \triangle(\bar{x}, \bar{y}) \in \Pi(\varepsilon, \eta)$ whenever the preferences fulfil (A1)-(A4).

Before we start observe that we want to determine the utility numbers (9) from the EU-representation $V(\cdot, \triangle(x, y))$ despite the fact that the lotteries inf $\triangle(x, y)$ and $\sup \triangle(x, y)$ do not belong to $\triangle(x, y)$ for $x<y$ and are therefore not necessarily represented by $V(\cdot, \triangle(x, y))$. Owed to the continuity of $V(\cdot, \triangle(x, y))$ on $\triangle(x, y)$ this will be no problem; however, as a consequence our procedure will become technically more involved.

By constructing (11) for all $\triangle(x, y), \triangle(\bar{x}, \bar{y}) \in \Pi(\varepsilon, \eta)$ we will proceed according to the following sequential order of SL-PL subsets

$$
\begin{aligned}
& \triangle\left(x_{1}, x_{1}\right), \triangle\left(x_{1}, x_{2}\right) \ldots, \ldots, \triangle\left(x_{1}, x_{n}\right) ; \\
& \triangle\left(x_{2}, x_{2}\right), \triangle\left(x_{2}, x_{3}\right) \ldots, \triangle\left(x_{2}, x_{n}\right) ; \\
& \ldots ; \\
& \triangle\left(x_{n}, x_{n}\right)
\end{aligned}
$$

That is, we start with

$$
V\left(\inf \triangle\left(x_{1}, x_{1}\right), \triangle\left(x_{1}, x_{1}\right)\right), V\left(\sup \triangle\left(x_{1}, x_{1}\right), \triangle\left(x_{1}, x_{1}\right)\right)
$$

which determines by (8) the utilities $V\left(\sigma, \triangle\left(x_{1}, x_{1}\right)\right)$ for all $\sigma \in \triangle\left(x_{1}, x_{1}\right)$. In a next step we presume $V\left(\cdot, \triangle\left(x_{1}, x_{1}\right)\right)$ as given and we derive then

$$
V\left(\inf \triangle\left(x_{1}, x_{2}\right), \triangle\left(x_{1}, x_{2}\right)\right), V\left(\sup \triangle\left(x_{1}, x_{2}\right), \triangle\left(x_{1}, x_{2}\right)\right)
$$


such that (10) will be fulfilled with $\triangle(x, y)=\triangle\left(x_{1}, x_{1}\right)$ and $\triangle(\bar{x}, \bar{y})=\triangle\left(x_{1}, x_{2}\right)$. This procedure is repeated until we derive the utility numbers $(11)$ for $\triangle(x, y)=\triangle\left(x_{n-1}, x_{1}\right)$ and $\triangle(\bar{x}, \bar{y})=\triangle\left(x_{n}, x_{n}\right)$. Moreover, observe that we have by transitivity of $\succeq$ : if (10) is fulfilled for $\triangle(x, y)=\triangle\left(x_{k}, x_{k}\right)$ and $\triangle(\bar{x}, \bar{y})=\triangle\left(x_{k+1}, x_{k+1}\right)$ as well as for $\triangle(x, y)=\triangle\left(x_{k+1}, x_{k+1}\right)$ and $\triangle(\bar{x}, \bar{y})=\triangle\left(x_{k+2}, x_{k+2}\right)$ then (10) is also fulfilled for $\triangle(x, y)=\triangle\left(x_{k}, x_{k}\right)$ and $\triangle(\bar{x}, \bar{y})=\triangle\left(x_{k+2}, x_{k+2}\right)$.

Thus, after having derived the utility numbers (11) fulfilling (10) for all $\triangle(1, y), \triangle(1, \bar{y}) \in$ $\Pi(\varepsilon, \eta)$ we consider now additionally all $\triangle(2, y), \triangle(2, \bar{y}) \in \Pi(\varepsilon, \eta)$. At first we would let $\triangle(\bar{x}, \bar{y})=\triangle\left(x_{2}, x_{2}\right)$ and $\triangle(x, y)=\triangle\left(x_{1}, x_{k}\right)$ with $k$ being the smallest number in $\{1, \ldots, n\}$ such that some lottery in $\triangle\left(x_{1}, x_{k}\right)$ will be preferred to some lottery in $\triangle\left(x_{2}, x_{2}\right)$. In a next step we would let $\triangle(x, y)=\triangle\left(x_{2}, x_{2}\right)$ and $\triangle(\bar{x}, \bar{y})=\triangle\left(x_{2}, x_{3}\right)$. Finally we will derive

$$
V\left(\inf \triangle\left(x_{n}, x_{n}\right), \triangle\left(x_{n}, x_{n}\right)\right), V\left(\sup \triangle\left(x_{n}, x_{n}\right), \triangle\left(x_{n}, x_{n}\right)\right)
$$

such that (10) is fulfilled for all $\triangle(x, y), \triangle(\bar{x}, \bar{y}) \in \Pi(\varepsilon, \eta)$.

Having sketched the whole procedure we describe now in some detail how the utility numbers

$$
\begin{aligned}
& V\left(\inf \triangle\left(x_{1}, x_{1}\right), \triangle\left(x_{1}, x_{1}\right)\right), V\left(\sup \triangle\left(x_{1}, x_{1}\right), \triangle\left(x_{1}, x_{1}\right)\right) \\
& V\left(\inf \triangle\left(x_{1}, x_{2}\right), \triangle\left(x_{1}, x_{2}\right)\right), V\left(\sup \triangle\left(x_{1}, x_{2}\right), \triangle\left(x_{1}, x_{2}\right)\right)
\end{aligned}
$$

can be derived. An application of the same reasoning to the remaining subsets will be straightforward and is therefore omitted.

Let

$$
\begin{gathered}
V\left(\inf \triangle\left(x_{1}, x_{1}\right), \triangle\left(x_{1}, x_{1}\right)\right)=0 \\
V\left(\sup \triangle\left(x_{1}, x_{1}\right), \triangle\left(x_{1}, x_{1}\right)\right)=1
\end{gathered}
$$

If the preferences do not overlap we simply apply (12) to obtain

$$
\begin{gathered}
V\left(\inf \triangle\left(x_{1}, x_{2}\right), \triangle\left(x_{1}, x_{2}\right)\right)=1 \\
V\left(\sup \triangle\left(x_{1}, x_{2}\right), \triangle\left(x_{1}, x_{2}\right)\right)=2
\end{gathered}
$$

and check whether there is no $\rho^{\prime} \in \triangle\left(x_{1}, x_{3}\right)$ such that $\sigma \succeq \rho^{\prime}$ for some $\sigma \in \triangle\left(x_{1}, x_{2}\right)$; and so forth.

Suppose now there was a $\rho^{\prime} \in \triangle\left(x_{1}, x_{2}\right)$ such that $\sigma \succeq \rho^{\prime}$ for some $\sigma \in \triangle\left(x_{1}, x_{1}\right)$. By step 1 there must exist $\sigma^{\prime}, \tau^{\prime} \in \triangle\left(x_{1}, x_{2}\right)$ and $\tau^{*} \in \triangle\left(x_{1}, x_{1}\right)$ such that

$$
\tau^{*} \sim \tau^{\prime} \succ \sigma^{\prime} \succ \inf \triangle\left(x_{1}, x_{1}\right)
$$


and

$$
\begin{aligned}
& V\left(\sigma^{\prime}, \triangle\left(x_{1}, x_{2}\right)\right)=V\left(\sigma^{*}, \triangle\left(x_{1}, x_{1}\right)\right) \\
& V\left(\tau^{\prime}, \triangle\left(x_{1}, x_{2}\right)\right)=V\left(\tau^{*}, \triangle\left(x_{1}, x_{1}\right)\right)
\end{aligned}
$$

Having determined the utilities of $\sigma^{\prime}, \tau^{\prime} \in \triangle\left(x_{1}, x_{2}\right)$ w.r.t. utility numbers assigned to lotteries in $\triangle\left(x_{1}, x_{1}\right)$ we proceed now by deriving

$$
V\left(\inf \triangle\left(x_{1}, x_{2}\right), \triangle\left(x_{1}, x_{2}\right)\right), V\left(\sup \triangle\left(x_{1}, x_{2}\right), \triangle\left(x_{1}, x_{2}\right)\right)
$$

from $V\left(\sigma^{\prime}, \triangle\left(x_{1}, x_{2}\right)\right)$ and $V\left(\tau^{\prime}, \triangle\left(x_{1}, x_{2}\right)\right)$.

Construct the sequence of lotteries $\left(\tau_{k}\right)_{k \in \mathbf{N}}$ such that

$$
\tau_{k}=\frac{1}{k+1} \cdot \tau^{\prime} \oplus\left(1-\frac{1}{k+1}\right) \cdot \sup \triangle\left(x_{1}, x_{2}\right)
$$

and verify: $\tau_{k} \in \triangle\left(x_{1}, x_{2}\right), \tau_{k} \succ \tau^{\prime}, \tau_{k+1} \succ \tau_{k}$ for all $k \in \mathbf{N}$, and

$$
\lim _{k \rightarrow \infty} \tau_{k}=\sup \triangle\left(x_{1}, x_{2}\right)
$$

Define now $\nu_{k} \in(0,1)$ for each $\tau_{k}, k \in \mathbf{N}$, implicitly by

$$
\tau^{\prime} \sim \nu_{k} \cdot \tau_{k} \oplus\left(1-\nu_{k}\right) \cdot \sigma^{\prime}
$$

and observe that $\nu_{k}$ is indeed well-defined as a unique number for every $\tau_{k}$ by (A3). By (A4) the induced sequence $\left(\nu_{k}\right)_{k \in \mathbf{N}}$ is monotonically decreasing and because it is bounded from below by zero there must exist a unique limit-point $\nu^{*}=\lim _{k \rightarrow \infty} \nu_{k}$.

By continuity of $V(\cdot, \triangle(x, y))$ on $\triangle(x, y)$ we obtain

$$
\begin{aligned}
V\left(\tau^{\prime}, \triangle\left(x_{1}, x_{2}\right)\right) & =\lim _{k \rightarrow \infty} V\left(\nu_{k} \cdot \tau_{k} \oplus\left(1-\nu_{k}\right) \cdot \sigma^{\prime}, \triangle\left(x_{1}, x_{2}\right)\right) \\
& =V\left(\nu^{*} \cdot \sup \triangle\left(x_{1}, x_{2}\right) \oplus\left(1-\nu^{*}\right) \cdot \sigma^{\prime}, \triangle\left(x_{1}, x_{2}\right)\right) \\
& =\nu^{*} * V\left(\sup \triangle\left(x_{1}, x_{2}\right), \triangle\left(x_{1}, x_{2}\right)\right)+\left(1-\nu^{*}\right) * V\left(\sigma^{\prime}, \triangle\left(x_{1}, x_{2}\right)\right)
\end{aligned}
$$

Rearranging gives

$$
V\left(\sup \triangle\left(x_{1}, x_{2}\right), \triangle\left(x_{1}, x_{2}\right)\right)=\frac{1}{\nu^{*}} * V\left(\tau^{\prime}, \triangle\left(x_{1}, x_{2}\right)\right)-\frac{\left(1-\nu^{*}\right)}{\nu^{*}} * V\left(\sigma^{\prime}, \triangle\left(x_{1}, x_{2}\right)\right)
$$

But this is our desired result.

Consider now the sequence $\left(\sigma_{k}\right)_{k \in \mathbf{N}}$ such that

$$
\sigma_{k}=\frac{1}{k+1} \cdot \sigma^{\prime} \oplus\left(1-\frac{1}{k+1}\right) \cdot \inf \triangle\left(x_{1}, x_{2}\right)
$$


and verify: $\sigma_{k} \in \triangle\left(x_{1}, x_{2}\right), \sigma^{\prime} \succ \sigma_{k}, \sigma_{k} \succ \sigma_{k+1}$ for all $k \in \mathbf{N}$, and

$$
\lim _{k \rightarrow \infty} \sigma_{k}=\inf \triangle\left(x_{1}, x_{2}\right)
$$

Define $\mu_{k} \in(0,1)$ for each $\sigma_{k}, k \in \mathbf{N}$, implicitly by

$$
\sigma^{\prime} \sim \mu_{k} \cdot \sigma_{k} \oplus\left(1-\mu_{k}\right) \cdot \tau^{\prime}
$$

The induced sequence $\left(\mu_{k}\right)_{k \in \mathbf{N}}$ is then monotonically increasing by (A4) and bounded from above by one such that there exists a unique limit-point $\mu^{*}=\lim _{k \rightarrow \infty} \mu_{k}$. By continuity of $V(\cdot, \triangle(x, y))$ on $\triangle(x, y)$

$$
V\left(\sigma^{\prime}, \triangle\left(x_{1}, x_{2}\right)\right)=\mu^{*} * V\left(\inf \triangle\left(x_{1}, x_{2}\right), \triangle\left(x_{1}, x_{2}\right)\right)+\left(1-\mu^{*}\right) * V\left(\tau^{\prime}, \triangle\left(x_{1}, x_{2}\right)\right)
$$

and rearranging gives the desired result

$$
V\left(\inf \triangle\left(x_{1}, x_{2}\right), \triangle\left(x_{1}, x_{2}\right)\right)=\frac{1}{\mu^{*}} * V\left(\sigma^{\prime}, \triangle\left(x_{1}, x_{2}\right)\right)-\frac{\left(1-\mu^{*}\right)}{\mu^{*}} * V\left(\tau^{\prime}, \triangle\left(x_{1}, x_{2}\right)\right)
$$

Finally, observe how we can now just compute backwards to express the utilities of $\sigma^{\prime}$ and $\tau^{\prime}$ by $(8)$

$$
\begin{aligned}
& V\left(\sigma^{\prime}, \triangle\left(x_{1}, x_{2}\right)\right) \\
= & \frac{\mu^{*}}{\nu^{*}+\mu^{*}-\nu^{*} \mu^{*}} * V\left(\inf \triangle\left(x_{1}, x_{2}\right), \triangle\left(x_{1}, x_{2}\right)\right)+\frac{\left(1-\mu^{*}\right) * \nu^{*}}{\nu^{*}+\mu^{*}-\nu^{*} \mu^{*}} * V\left(\sup \triangle\left(x_{1}, x_{2}\right), \triangle\left(x_{1}, x_{2}\right)\right)
\end{aligned}
$$

and

$$
\begin{aligned}
& V\left(\tau^{\prime}, \triangle\left(x_{1}, x_{2}\right)\right) \\
= & \frac{\left(1-\nu^{*}\right) * \mu^{*}}{\nu^{*}+\mu^{*}-\nu^{*} \mu^{*}} * V\left(\inf \triangle\left(x_{1}, x_{2}\right), \triangle\left(x_{1}, x_{2}\right)\right)+\frac{\nu^{*}}{\nu^{*}+\mu^{*}-\nu^{*} \mu^{*}} * V\left(\sup \triangle\left(x_{1}, x_{2}\right), \triangle\left(x_{1}, x_{2}\right)\right)
\end{aligned}
$$

Part B. We demonstrate now that all subset-dependent EU-functionals $V(\cdot, \triangle(x, y))$, $\triangle(x, y) \in \Pi(\varepsilon, \eta)$, have to satisfy (4) whenever the preferences fulfil (A1)-(A4). The proof for (5) is analog and therefore omitted.

Suppose on the contrary that there is some sequence $\left(\sigma_{k}\right)_{k \in \mathbf{N}}$ with $\lim _{k \rightarrow \infty} \sigma_{k}=\sigma$ such that $\sigma_{k} \in \triangle(x, y)$ for all $k \in N$ and $\sigma \in \triangle(\bar{x}, \bar{y})$ and we have

$$
\lim _{k \rightarrow \infty} V\left(\sigma_{k}, \triangle(x, y)\right)>V(\sigma, \triangle(\bar{x}, \bar{y}))
$$

for $\bar{x} \geq x, \bar{y} \geq y$, and $\triangle(x, y) \neq \triangle(\bar{x}, \bar{y})$. 
Recall that $\sup \triangle(\bar{x}, \bar{y}) \succ_{F O S D} \sigma$, for all $\sigma \in \triangle(\bar{x}, \bar{y})$ with $\sigma \neq \sup \triangle(\bar{x}, \bar{y})$. Observe now that for all $\lambda \in(0,1)$

$$
\lambda \cdot \sup \triangle(\bar{x}, \bar{y}) \oplus(1-\lambda) \cdot \sigma \in \triangle(\bar{x}, \bar{y})
$$

and by continuity of $V(\cdot, \triangle(\bar{x}, \bar{y}))$ there must exist under assumption (17) some $\lambda \in$ $(0,1)$ such that

$$
\lim _{k \rightarrow \infty} V\left(\sigma_{k}, \triangle(x, y)\right)>V(\lambda \cdot \tau \oplus(1-\lambda) \cdot \sigma, \triangle(\bar{x}, \bar{y}))
$$

Quasiconcavity of $\succ_{F O S D}$ implies

$$
\lambda \cdot \tau \oplus(1-\lambda) \cdot \sigma \succ_{F O S D} \sigma
$$

By continuity of $\succ_{F O S D}$ there is some $M \in \mathbf{N}$ such that

$$
\lambda \cdot \tau \oplus(1-\lambda) \cdot \sigma \succ_{F O S D} \sigma_{k}
$$

for all $k \geq M$. And by (A4)

$$
V(\lambda \cdot \tau \oplus(1-\lambda) \cdot \sigma, \triangle(\bar{x}, \bar{y}))>V\left(\sigma_{k}, \triangle(x, y)\right)
$$

for all $k \geq M$. Thus

$$
V(\lambda \cdot \tau \oplus(1-\lambda) \cdot \sigma, \triangle(\bar{x}, \bar{y})) \geq \lim _{k \rightarrow \infty} V\left(\sigma_{k}, \triangle(x, y)\right)
$$

A contradiction to (18).

Part C. After having proved that all preferences fulfilling (A1)-(A4) are representable by (2) it remains to prove the converse; i.e., any utility function (2) represents some preferences that fulfil (A1)-(A4). This is easily checked for the axioms (A1)-(A3), and therefore omitted. Let us now prove that the conditions (4) and (5) are sufficient for guaranteeing (A4).

Suppose on the contrary that there are $\sigma, \tau \in \triangle(X)$ such that $\tau \succeq_{F O S D} \sigma$ but

$$
U(\sigma)>U(\tau)
$$

Observe at first that by construction of $\Pi(\varepsilon, \eta): \tau \succeq_{F O S D} \sigma$ only if $\sigma \in \triangle(x, y)$ and $\tau \in \triangle(\bar{x}, \bar{y})$ with $\bar{x} \geq x$ and $\bar{y} \geq y$. Moreover, the SL-PL subset dependent EUrepresentation $V(\cdot, \triangle(x, y))$ implies that there can not occur a violation of monotonicity w.r.t. FOSD for any $\sigma, \tau \in \triangle(x, y)$. Thus, (A4) can only be violated if $\sigma \in \triangle(x, y)$ and $\tau \in \triangle(\bar{x}, \bar{y})$ with $\bar{x} \geq x$ and $\bar{y} \geq y$, and $\triangle(x, y) \neq \triangle(\bar{x}, \bar{y})$. 
Construct now the net $\left(\tau_{\lambda}\right)_{\lambda \in(0,1)}$ such that

$$
\tau_{\lambda}=(1-\lambda) \cdot \tau \oplus \lambda \cdot \sigma
$$

and observe that by quasiconcavity of $\succeq_{F O S D}$ :

$$
\tau \succeq_{F O S D} \tau_{\lambda} \succeq_{F O S D} \tau_{\mu}
$$

for all $\mu \in(0,1]$ if $\mu>\lambda$. By construction of $\Pi(\varepsilon, \eta)$ there must exist a unique $\lambda^{*}$ such that either

(i.) $\tau_{\lambda^{*}} \in \triangle(\bar{x}, \bar{y})$ and $\tau_{\lambda} \in \triangle(x, y)$ for all $\lambda>\lambda^{*}$, or

(ii.) $\tau_{\lambda^{*}} \in \triangle(x, y)$ and $\tau_{\lambda} \in \triangle(\bar{x}, \bar{y})$ for all $\lambda<\lambda^{*}$.

Let us consider case (i) where sequences in $\triangle(x, y)$ may have a limit-point in $\triangle(\bar{x}, \bar{y})$ but not vice versa. (Case (ii.) is analogously proved via condition (5) and therefore omitted.)

Construct the sequence $\left(\sigma_{k}\right)_{k \in \mathbf{N}}$ such that

$$
\sigma_{k}=\left(1-\frac{1}{k}\right) \cdot \tau_{\lambda^{*}} \oplus \frac{1}{k} \cdot \sigma
$$

and observe that $\sigma_{k+1} \succeq \sigma_{k}$ by (A2) which implies

$$
V\left(\sigma_{k+1}, \triangle(x, y)\right)=U\left(\sigma_{k+1}\right) \geq U\left(\sigma_{k}\right)=V\left(\sigma_{k}, \triangle(x, y)\right)
$$

since $\sigma_{k+1}, \sigma_{k} \in \triangle(x, y)$ for all $k \in \mathbf{N}$. Thus,

$$
\lim _{k \rightarrow \infty} V\left(\sigma_{k}, \triangle(x, y)\right)=V\left(\tau_{\lambda^{*}}, \triangle(x, y)\right) \geq V(\sigma, \triangle(x, y))
$$

Analogously

$$
V(\tau, \triangle(\bar{x}, \bar{y}))=U(\tau) \geq U\left(\tau_{\lambda^{*}}\right)=V\left(\tau_{\lambda^{*}}, \triangle(\bar{x}, \bar{y})\right)
$$

The condition (4) claims now

$$
V\left(\tau_{\lambda^{*}}, \triangle(\bar{x}, \bar{y})\right) \geq V\left(\tau_{\lambda^{*}}, \triangle(x, y)\right)
$$

and we obtain

$$
U(\tau) \geq U(\sigma)
$$

A contradiction to (19). 


\section{$7 \quad$ References}

Allais, M. (1979), "The Foundation of a Positive Theory of Choice Involving Risk and a Criticism of the Postulates and Axioms of the American School". Part II in Allais, M., and O. Hagen [eds.], Expected Utility Hypotheses and the Allais Paradox, D. Reidel: Dordrecht etc.

Chateauneuf, A., Eichberger, J., and S. Grant (2003), "Choice under Uncertainty with the Best and Worst in Mind: Neo-additive Capacities", Working Paper 03-10, Sonderforschungsbereich 504 Universität Mannheim.

Chew, S. H., and W. Waller (1986), "Risk Aversion in the Theory of Expected Utility with Rank Dependent Probabilities", Journal of Economic Theory 42, 370-381.

Cohen, M. (1992), "Security Level, Potential Level, Expected Utility: A Three-Criteria Decision Model Under Risk", Theory and Decision 33, 101-104.

Dow, J., and S.C.R. Werlang (1994), "Nash Equilibrium under Uncertainty: Breaking down Backward Induction", Journal of Economic Theory 64, 305-324.

Eichberger, J., and D. Kelsey (1999), "E-Capacities and the Ellsberg Paradox", Theory and Decision 46, 107-140.

Essid, S. (1997), "Choice under risk with certainty and potential effects: A general axiomatic model", Mahematical Social Sciences 34, 223-247.

Gilboa, I. (1988), "A Combination of Expected Utility and Maxmin Decision Criteria", Journal of Mathematical Psychology 32, 405-420.

Harless, D.W., and C.F. Camerer (1994), "The Predictive Utility of Generalized Expected Utility Theories", Econometrica 62, 1251-1289. 
Jaffray, J.-Y. (1988), "Choice under Risk and the Security Factor: An Axiomatic Model", Theory and Decision 24, 169-200.

Karni, E., and D. Schmeidler (1991), "Utility Theory With Uncertainty" in: Hildenbrand, W. and H. Sonnenschein [eds.], Handbook of Mathematical Economics, Vol. IV, North-Holland: Amsterdam etc., 1763-1831.

Lopes, L. L. (1987), "Between Hope And Fear: The Psychology Of Risk" in: Berkowitz, L. [ed.], Advances In Experimental Social Psychology, Vol. 20, New York: Academic Press, 255-295.

Sjöberg, L. (1999), "Consequences of perceived risk: Demand for mitigation", Journal of Risk Research 2, 129-149.

Sjöberg, L. (2000), "Consequences matter, 'risk' is marginal", Journal of Risk Research 3, 287-295.

Sopher, B., and G. Gigliotti (1993), "A Test of Generalized Expected Uitlity", Theory and Decision 35, 75-106.

Schmidt, U. (2003)," Alternatives to Expected Utility: Some Formal Theories", in: P.J. Hammond, S. Barberá, and C. Seidl [eds.], Handbook of Utility Theory Vol. II, Kluwer, Boston, forthcoming.

Starmer, C. (2000), "Developments in Non-Expected Utility Theory: The Hunt for a Descriptive Theory of Choice under Risk", Journal of Economic Literature 38, 332-382.

Stone, E. R., J. F. Yates, and A. M. Parker (1994), "Risk Communication: Absolute versus Relative Expressions of Low-Probability Risks", Organizational Behavior and Human Decision Processes 60, 387-408.

Sugden, R. (2003)," Alternatives to Expected Utility: Foundation", in: in: P.J. Hammond, S. Barberá, and C. Seidl [eds.], Handbook of Utility Theory Vol. II, Kluwer, Boston, forthcoming. 
$(\$ 5 \mathrm{M} \bullet 1)$

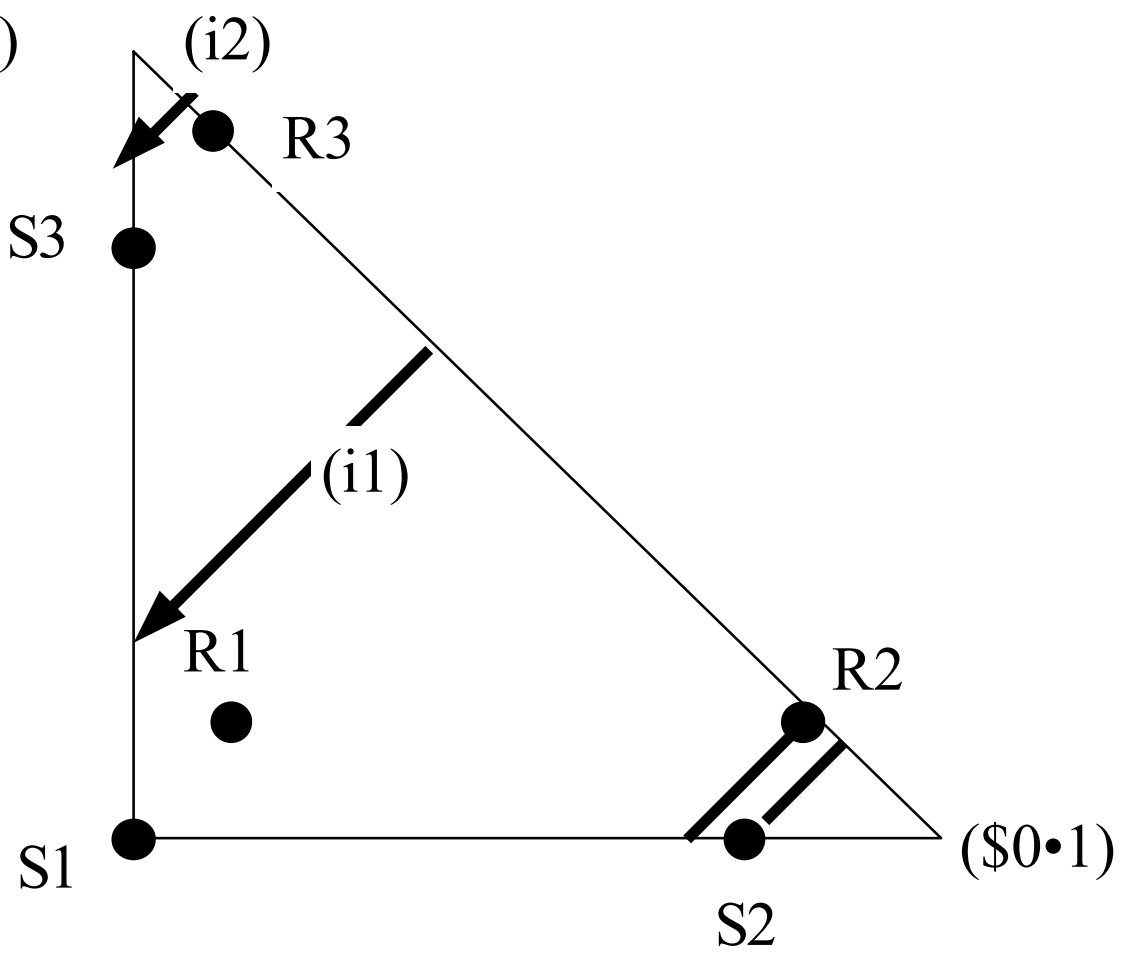

Figure 1. By a security effect $\mathrm{S} 1$ is indifferent to the points on the indifference curve (i1) to the effect that $\mathrm{S} 1$ is preferred to R1. But then the existing SL,PL-models require S3 to be indifferent to the points on (i2). Thus, S3 must be preferred to R3. A violation of the choice pattern $(\mathrm{S} 1, \mathrm{R} 2, \mathrm{R} 3)$.

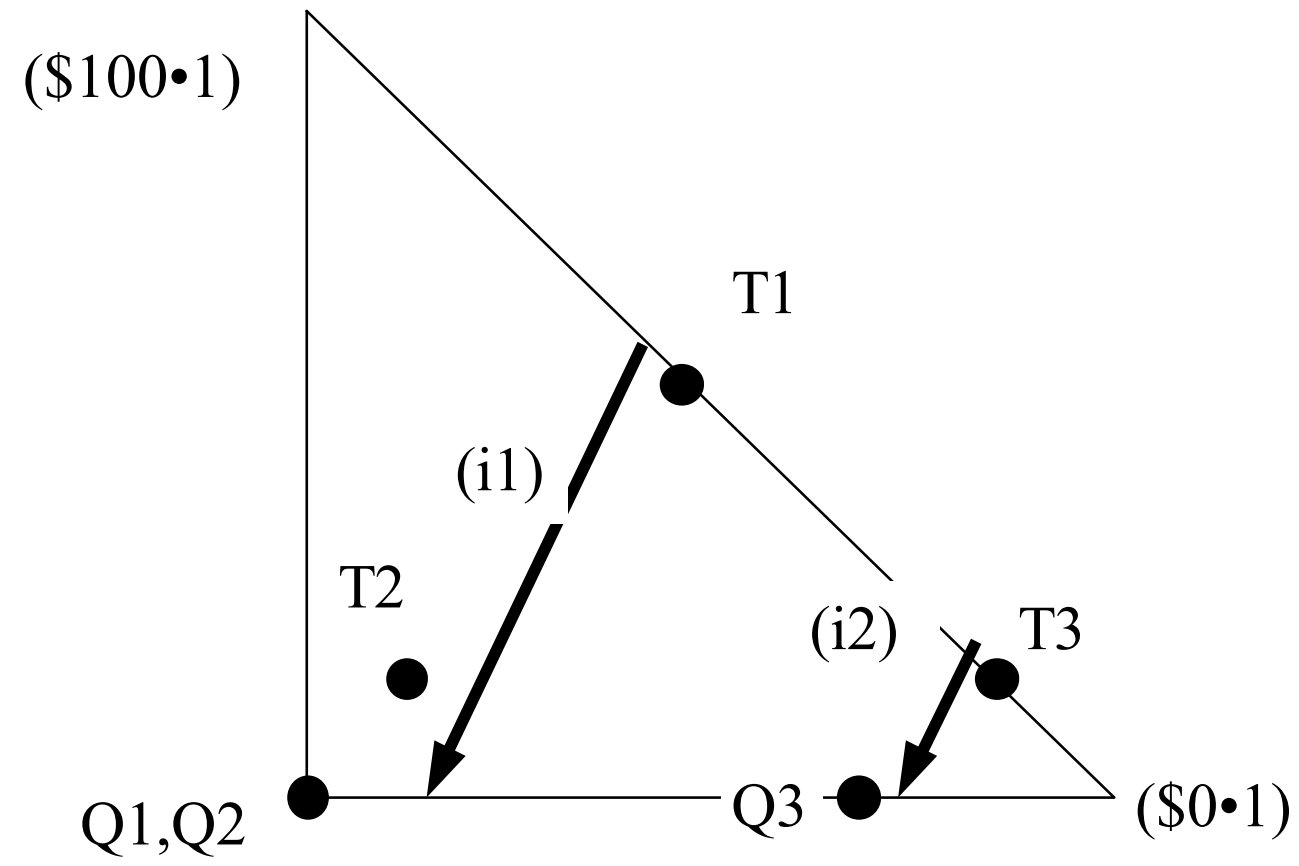

Figure 2. By a potential effect Q1 is indifferent to the points on (i1), i.e., Q1 is preferred to T1 but not to T2. Moreover, Q3, being indifferent to the points on (i2), must be preferred to $\mathrm{T} 3$ - a violation of the choice pattern (Q1,T2,T3). 


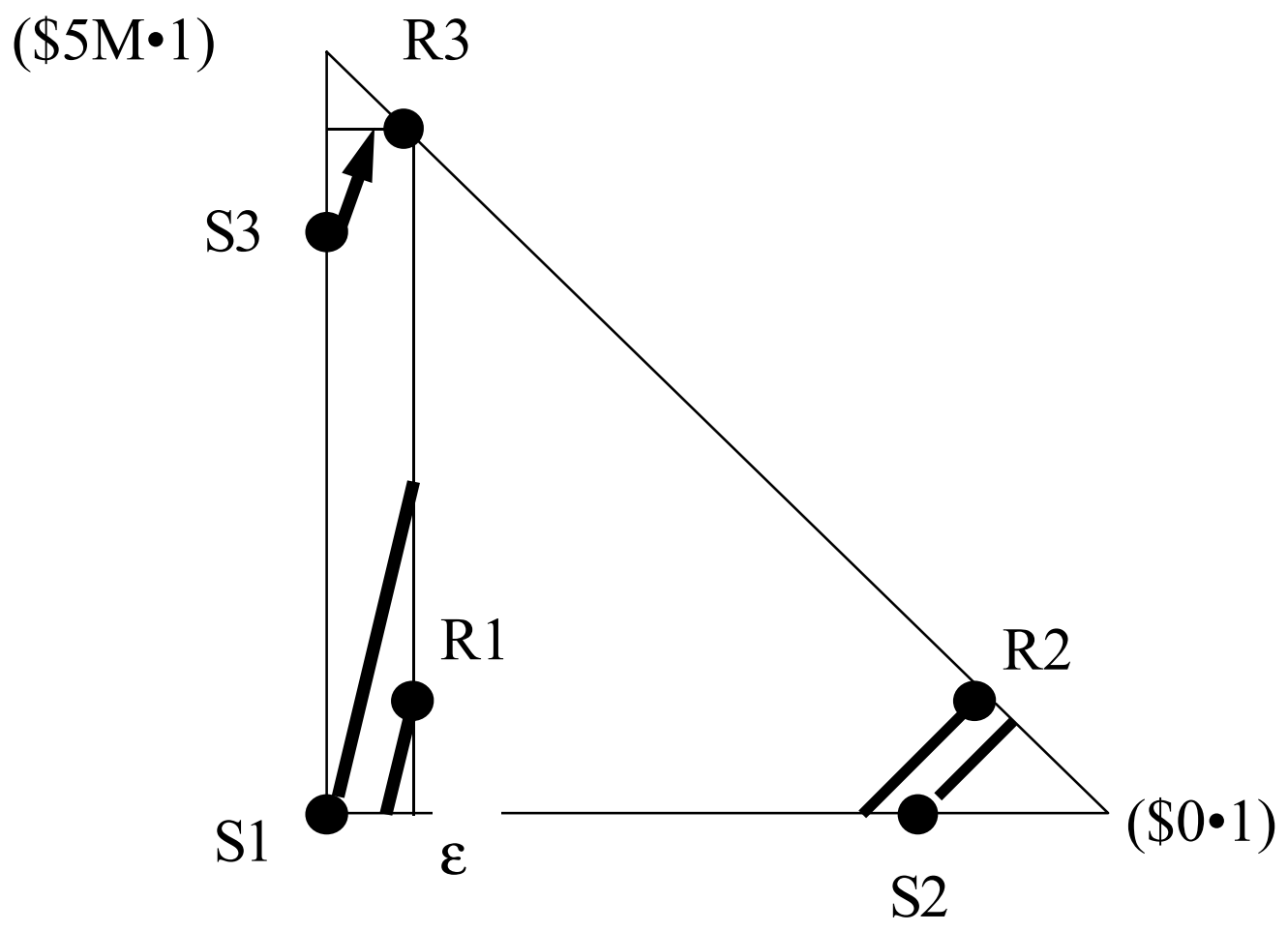

Figure 3. Introduction of a threshold for security levels and steeper slopes of the indifference curves on higher security levels can accommodate the choice pattern $(\mathrm{S} 1, \mathrm{R} 2, \mathrm{R} 3)$.

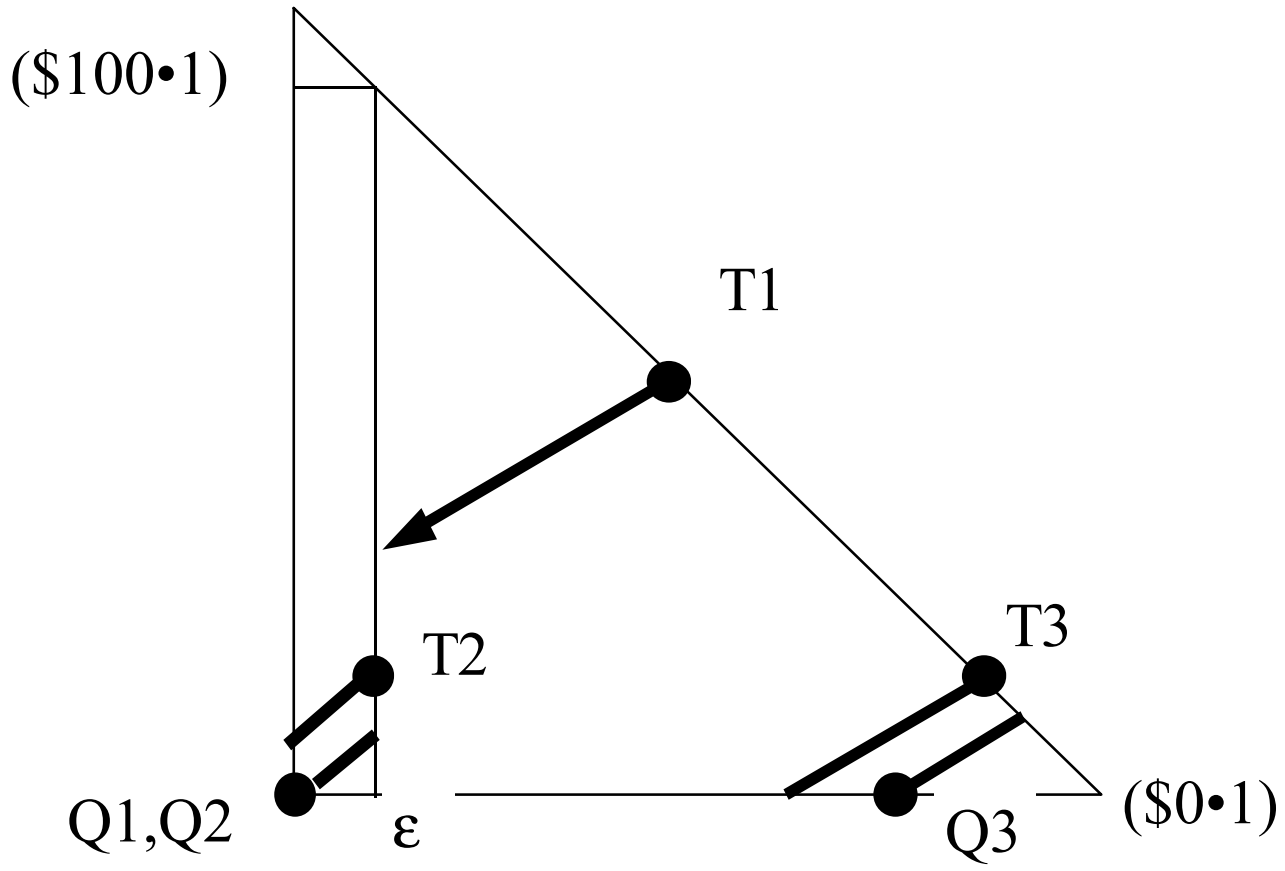

Figure 4. A threshold for security levels allows for the choice pattern (Q1,T2,T3). The slopes of the indifference curves may be the same for all security levels. 


\begin{tabular}{|c|c|c|}
\hline Nr. & Author & Title \\
\hline $03-32$ & $\begin{array}{l}\text { Siegfried K. Berninghaus } \\
\text { Christian Korth } \\
\text { Stefan Napel }\end{array}$ & Reciprocity - an indirect evolutionary analysis \\
\hline 03-31 & $\begin{array}{l}\text { Peter Albrecht } \\
\text { Cemil Kantar }\end{array}$ & $\begin{array}{l}\text { Random Walk oder Mean Reversion? Eine } \\
\text { statistische Analyse des Kurs/Gewinn-Verhältnisses } \\
\text { für den deutschen Aktienmarkt }\end{array}$ \\
\hline $03-30$ & $\begin{array}{l}\text { Jürgen Eichberger } \\
\text { David Kelsey } \\
\text { Burkhard Schipper }\end{array}$ & Ambiguity and Social Interaction \\
\hline 03-29 & $\begin{array}{l}\text { Ulrich Schmidt } \\
\text { Alexander Zimper }\end{array}$ & $\begin{array}{l}\text { Security And Potential Level Preferences With } \\
\text { Thresholds }\end{array}$ \\
\hline $03-28$ & Alexander Zimper & $\begin{array}{l}\text { Uniqueness Conditions for Point-Rationalizable } \\
\text { Solutions of Games with Metrizable Strategy Sets }\end{array}$ \\
\hline $03-27$ & $\begin{array}{l}\text { Jürgen Eichberger } \\
\text { David Kelsey }\end{array}$ & Sequential Two-Player Games with Ambiguity \\
\hline 03-26 & $\begin{array}{l}\text { Alain Chateauneuf } \\
\text { Jürgen Eichberger } \\
\text { Simon Grant }\end{array}$ & $\begin{array}{l}\text { A Simple Axiomatization and Constructive } \\
\text { Representation Proof for Choquet Expected Utility }\end{array}$ \\
\hline $03-25$ & Volker Stocké & $\begin{array}{l}\text { Informationsverfügbarkeit und Response-Effects: } \\
\text { Die Prognose von Einflüssen unterschiedlich } \\
\text { kategorisierter Antwortskalen durch } \\
\text { Antwortsicherheiten und Antwortlatenzen }\end{array}$ \\
\hline 03-24 & Volker Stocké & $\begin{array}{l}\text { Entstehungsbedingungen von Antwortverzerrungen } \\
\text { durch soziale Erwünschtheit. Ein Vergleich der } \\
\text { Prognosen der Rational-Choice Theorie und des } \\
\text { Modells der Frame-Selektion }\end{array}$ \\
\hline $03-23$ & Daniel Schunk & $\begin{array}{l}\text { Modeling the Use of Nonrenewable Resources } \\
\text { Using a Genetic Algorithm }\end{array}$ \\
\hline 03-22 & $\begin{array}{l}\text { Brian Deal } \\
\text { Daniel Schunk }\end{array}$ & $\begin{array}{l}\text { Spatial Dynamic Modeling and Urban Land Use } \\
\text { Transformation: An Ecological Simulation } \\
\text { Approach to Assessing the Costs of Urban Sprawl }\end{array}$ \\
\hline
\end{tabular}

\begin{tabular}{|c|c|c|}
\hline Nr. & Author & $\begin{array}{l}\text { Title } \\
\end{array}$ \\
\hline $03-21$ & $\begin{array}{l}\text { Thomas Gschwend } \\
\text { Franz Urban Pappi }\end{array}$ & Stimmensplitting und Koalitionswahl \\
\hline $03-20$ & $\begin{array}{l}\text { Thomas Langer } \\
\text { Martin Weber }\end{array}$ & $\begin{array}{l}\text { Does Binding or Feeback Influence Myopic Loss } \\
\text { Aversion - An Experimental Analysis }\end{array}$ \\
\hline $03-19$ & $\begin{array}{l}\text { Peter Albrecht } \\
\text { Carsten Weber }\end{array}$ & $\begin{array}{l}\text { Asset/Liability Management of German Life } \\
\text { Insurance Companies: A Value-at-Risk Approach } \\
\text { in the Presence of Interest Rate Guarantees }\end{array}$ \\
\hline 03-18 & Markus Glaser & $\begin{array}{l}\text { Online Broker Investors: Demographic } \\
\text { Information, Investment Strategy, Portfolio } \\
\text { Positions, and Trading Activity }\end{array}$ \\
\hline 03-17 & $\begin{array}{l}\text { Markus Glaser } \\
\text { Martin Weber }\end{array}$ & $\begin{array}{l}\text { September } 11 \text { and Stock Return Expectations of } \\
\text { Individual Investors }\end{array}$ \\
\hline $03-16$ & $\begin{array}{l}\text { Siegfried K. Berninghaus } \\
\text { Bodo Vogt }\end{array}$ & Network Formation and Coordination Games \\
\hline $03-15$ & $\begin{array}{l}\text { Johannes Keller } \\
\text { Herbert Bless }\end{array}$ & $\begin{array}{l}\text { When negative expectancies turn into negative } \\
\text { performance: The role of ease of retrieval. }\end{array}$ \\
\hline $03-14$ & $\begin{array}{l}\text { Markus Glaser } \\
\text { Markus Nöth } \\
\text { Martin Weber }\end{array}$ & Behavioral Finance \\
\hline $03-13$ & Hendrik Hakenes & Banks as Delegated Risk Managers \\
\hline $03-12$ & Elena Carletti & $\begin{array}{l}\text { The Structure of Bank Relationships, Endogenous } \\
\text { Monitoring and Loan Rates }\end{array}$ \\
\hline 03-11 & Isabel Schnabel & $\begin{array}{l}\text { The Great Banks` Depression - Deposit } \\
\text { Withdrawals in the German Crisis of } 1931\end{array}$ \\
\hline $03-10$ & $\begin{array}{l}\text { Alain Chateauneuf } \\
\text { Jürgen Eichberger } \\
\text { Simon Grant }\end{array}$ & $\begin{array}{l}\text { Choice under Uncertainty with the Best and Worst } \\
\text { in Mind: Neo-additive Capacities. }\end{array}$ \\
\hline 03-09 & $\begin{array}{l}\text { Peter Albrecht } \\
\text { Carsten Weber }\end{array}$ & $\begin{array}{l}\text { Combined Accumulation- and Decumulation-Plans } \\
\text { with Risk-Controlled Capital Protection }\end{array}$ \\
\hline
\end{tabular}

SONDERForschungsBereich 504 WORKING PAPER SERIES

\begin{tabular}{|c|c|c|}
\hline Nr. & Author & $\begin{array}{l}\text { Title } \\
\end{array}$ \\
\hline 03-08 & $\begin{array}{l}\text { Hans-Martin von Gaudecker } \\
\text { Carsten Weber }\end{array}$ & $\begin{array}{l}\text { Surprises in a Growing Market Niche - An } \\
\text { Evaluation of the German Private Annuities Market }\end{array}$ \\
\hline 03-07 & $\begin{array}{l}\text { Markus Glaser } \\
\text { Martin Weber }\end{array}$ & Overconfidence and Trading Volume \\
\hline 03-06 & $\begin{array}{l}\text { Markus Glaser } \\
\text { Thomas Langer } \\
\text { Martin Weber }\end{array}$ & $\begin{array}{l}\text { On the trend recognition and forecasting ability of } \\
\text { professional traders }\end{array}$ \\
\hline 03-05 & Geschäftsstelle & Jahresbericht 2002 \\
\hline 03-04 & $\begin{array}{l}\text { Oliver Kirchkamp } \\
\text { Rosemarie Nagel }\end{array}$ & $\begin{array}{l}\text { No imitation - on local and group interaction, } \\
\text { learning and reciprocity in prisoners } \\
\text { break }\end{array}$ \\
\hline $03-03$ & $\begin{array}{l}\text { Michele Bernasconi } \\
\text { Oliver Kirchkamp } \\
\text { Paolo Paruolo }\end{array}$ & $\begin{array}{l}\text { Expectations and perceived causality in fiscal } \\
\text { policy: an experimental analysis using real world } \\
\text { data }\end{array}$ \\
\hline 03-02 & Peter Albrecht & Risk Based Capital Allocation \\
\hline 03-01 & Peter Albrecht & Risk Measures \\
\hline $02-51$ & $\begin{array}{l}\text { Peter Albrecht } \\
\text { Ivica Dus } \\
\text { Raimond Maurer } \\
\text { Ulla Ruckpaul }\end{array}$ & Cost Average-Effekt: Fakt oder Mythos? \\
\hline $02-50$ & $\begin{array}{l}\text { Thomas Langer } \\
\text { Niels Nauhauser }\end{array}$ & $\begin{array}{l}\text { Zur Bedeutung von Cost-Average-Effekten bei } \\
\text { Einzahlungsplänen und Portefeuilleumschichtungen }\end{array}$ \\
\hline $02-49$ & $\begin{array}{l}\text { Alexander Klos } \\
\text { Thomas Langer } \\
\text { Martin Weber }\end{array}$ & $\begin{array}{l}\text { Über kurz oder lang - Welche Rolle spielt der } \\
\text { Anlagehorizont bei Investitionsentscheidungen? }\end{array}$ \\
\hline $02-48$ & Isabel Schnabel & The German Twin Crisis of 1931 \\
\hline $02-47$ & $\begin{array}{l}\text { Axel Börsch-Supan } \\
\text { Annamaria Lusardi }\end{array}$ & Saving Viewed from a Cross-National Perspective \\
\hline $02-46$ & $\begin{array}{l}\text { Isabel Schnabel } \\
\text { Hyun Song Shin }\end{array}$ & Foreshadowing LTCM: The Crisis of 1763 \\
\hline
\end{tabular}

SONDERFORSCHUNGSBereich 504 WORKING PAPER SERIES

\begin{tabular}{|c|c|c|}
\hline$\overline{\mathrm{Nr} .}$ & Author & Title \\
\hline $02-45$ & Ulrich Koch & $\begin{array}{l}\text { Inkrementaler Wandel und adaptive Dynamik in } \\
\text { Regelsystemen }\end{array}$ \\
\hline $02-44$ & Alexander Klos & Die Risikoprämie am deutschen Kapitalmarkt \\
\hline $02-43$ & $\begin{array}{l}\text { Markus Glaser } \\
\text { Martin Weber }\end{array}$ & $\begin{array}{l}\text { Momentum and Turnover: Evidence from the } \\
\text { German Stock Market }\end{array}$ \\
\hline $02-42$ & $\begin{array}{l}\text { Mohammed Abdellaoui } \\
\text { Frank Voßmann } \\
\text { Martin Weber }\end{array}$ & $\begin{array}{l}\text { An Experimental Analysis of Decision Weights in } \\
\text { Cumulative Prospect Theory under Uncertainty }\end{array}$ \\
\hline $02-41$ & $\begin{array}{l}\text { Carlo Kraemer } \\
\text { Martin Weber }\end{array}$ & $\begin{array}{l}\text { To buy or not to buy: Why do people buy too much } \\
\text { information? }\end{array}$ \\
\hline $02-40$ & Nikolaus Beck & $\begin{array}{l}\text { Kumulation und Verweildauerabhängigkeit von } \\
\text { Regeländerungen }\end{array}$ \\
\hline $02-39$ & Eric Igou & $\begin{array}{l}\text { The Role of Lay Theories of Affect Progressions in } \\
\text { Affective Forecasting }\end{array}$ \\
\hline $02-38$ & $\begin{array}{l}\text { Eric Igou } \\
\text { Herbert Bless }\end{array}$ & $\begin{array}{l}\text { My future emotions versus your future emotions: } \\
\text { The self-other effect in affective forecasting }\end{array}$ \\
\hline $02-37$ & $\begin{array}{l}\text { Stefan Schwarz } \\
\text { Dagmar Stahlberg } \\
\text { Sabine Sczesny }\end{array}$ & $\begin{array}{l}\text { Denying the foreseeability of an event as a means of } \\
\text { self-protection. The impact of self-threatening } \\
\text { outcome information on the strength of the } \\
\text { hindsight bias }\end{array}$ \\
\hline $02-36$ & $\begin{array}{l}\text { Susanne Abele } \\
\text { Herbert Bless } \\
\text { Karl-Martin Ehrhart }\end{array}$ & $\begin{array}{l}\text { Social Information Processing in Strategic Decision } \\
\text { Making: Why Timing Matters }\end{array}$ \\
\hline $02-35$ & Joachim Winter & $\begin{array}{l}\text { Bracketing effects in categorized survey questions } \\
\text { and the measurement of economic quantities }\end{array}$ \\
\hline $02-34$ & Joachim Winter & $\begin{array}{l}\text { Design effects in survey-based measures of } \\
\text { household consumption }\end{array}$ \\
\hline $02-33$ & $\begin{array}{l}\text { Stefan Schwarz } \\
\text { Dagmar Stahlberg }\end{array}$ & $\begin{array}{l}\text { Motivational influences on the strength of the } \\
\text { hindsight bias }\end{array}$ \\
\hline
\end{tabular}




\begin{tabular}{|c|c|c|c|c|c|}
\hline Nr. & Author & Title & $\begin{array}{ll}\mathrm{Nr} . \\
\end{array}$ & Author & Title \\
\hline $02-32$ & $\begin{array}{l}\text { Stefan Schwarz } \\
\text { Dagmar Stahlberg }\end{array}$ & $\begin{array}{l}\text { Strength of hindsight bias as a consequence of } \\
\text { meta-cognitions }\end{array}$ & $02-21$ & $\begin{array}{l}\text { Axel Börsch-Supan } \\
\text { Florian Heiss } \\
\text { Miki Seko }\end{array}$ & $\begin{array}{l}\text { Housing Demand in Germany and Japan - Paper in } \\
\text { memoriam of Stephen Mayo }\end{array}$ \\
\hline $02-31$ & Roman Grunwald & $\begin{array}{l}\text { Inter-Organisationales Lernen und die Integration } \\
\text { spezialisierten Wissens in Kooperationen - Eine } \\
\text { empirische Untersuchung anhand von kooperativen } \\
\text { Entwicklungsprojekten }\end{array}$ & $02-20$ & $\begin{array}{l}\text { Siegfried K. Berninghaus } \\
\text { Karl-Martin Ehrhart }\end{array}$ & The power of ESS: An experimental study \\
\hline $02-30$ & Martin Hellwig & $\begin{array}{l}\text { The Relation Between Real Wage Rates and } \\
\text { Employment: An Intertemporal }\end{array}$ & $02-19$ & $\begin{array}{l}\text { Douglas Gale } \\
\text { Martin Hellwig }\end{array}$ & $\begin{array}{l}\text { Competitive Insurance Markets with Asymmetric } \\
\text { Information: A Cournot-Arrow-Debreu Approach* }\end{array}$ \\
\hline & & General-Equilibrium Analysis & $02-18$ & $\begin{array}{l}\text { Michele Bernasconi } \\
\text { Oliver Kirchkamp }\end{array}$ & $\begin{array}{l}\text { The Expectations view on fiscal policy - An } \\
\text { experiment using real world data }\end{array}$ \\
\hline $02-29$ & $\begin{array}{l}\text { Moshe Ben-Akiva } \\
\text { Daniel McFadden } \\
\text { Kenneth Train } \\
\text { Axel Börsch-Supan }\end{array}$ & Hybrid Choice Models: Progress and Challenges & $02-17$ & $\begin{array}{l}\text { Oliver Kirchkamp } \\
\text { Rosemarie Nagel }\end{array}$ & $\begin{array}{l}\text { Reinforcement, repeated games, and local } \\
\text { interaction }\end{array}$ \\
\hline $02-28$ & $\begin{array}{l}\text { Angelika Eymann } \\
\text { Axel Börsch-Supan }\end{array}$ & Risk Attitude, Impatience, and Asset Choice & $02-16$ & Volker Stocké & $\begin{array}{l}\text { Die Vorhersage von Fragenreihenfolgeeffekten } \\
\text { durch Antwortlatenzen: Eine Validierungsstudie }\end{array}$ \\
\hline $02-27$ & $\begin{array}{l}\text { Rob Euwals } \\
\text { Axel Börsch-Supan } \\
\text { Alexander Ludwig }\end{array}$ & Aging and International Capital Flows & $02-15$ & $\begin{array}{l}\text { Thomas Kittsteiner } \\
\text { Jörg Nikutta } \\
\text { Eyal Winter }\end{array}$ & Discounting in Sequential Auctions \\
\hline $02-26$ & $\begin{array}{l}\text { Joachim Winter } \\
\text { Rüdiger F. Pohl }\end{array}$ & Gustatory hindsight bias & $02-14$ & Christian Ewerhart & $\begin{array}{l}\text { Banks, Internal Models and the Problem of Adverse } \\
\text { Selection }\end{array}$ \\
\hline & $\begin{array}{l}\text { Stefan Schwarz } \\
\text { Sabine Sczesny } \\
\text { Dagmar Stahlberg }\end{array}$ & & $02-13$ & $\begin{array}{l}\text { Christian Ewerhart } \\
\text { Eyal Winter }\end{array}$ & $\begin{array}{l}\text { Limited Backward Induction as an Expression of } \\
\text { Bayesian Rationality }\end{array}$ \\
\hline $02-25$ & Axel Börsch-Supan & $\begin{array}{l}\text { What We Know and What We Do NOT Know } \\
\text { About the Willingness to Provide Self-Financed } \\
\text { Old-Age Insurance }\end{array}$ & $02-12$ & Christian Ewerhart & $\begin{array}{l}\text { Enabling Goal-Directed Planning and Control: } \\
\text { Experiences with the Implementation of Value } \\
\text { Management in an Internationally Operating Stock } \\
\text { Exchange }\end{array}$ \\
\hline $02-24$ & Florian Heiss & Specification(s) of Nested Logit Models & $02-11$ & $\begin{array}{l}\text { Christian Ewerhart } \\
\text { Karsten Fieseler }\end{array}$ & Procurement Auctions and Unit-Price Contracts \\
\hline $02-23$ & Axel Börsch-Supan & $\begin{array}{l}\text { Kann die Finanz- und Sozialpolitik die } \\
\text { Auswirkungen der Bevölkerungsalterung auf den } \\
\text { Arbeitsmarkt lindern? }\end{array}$ & $02-10$ & Susanne Abele & How to Influence Cooperation Subtly \\
\hline $02-22$ & Tito Boeri & Would you Like to Reform the Pension System? & $02-01$ & Geschäftsstelle & Jahresbericht 2001 \\
\hline
\end{tabular}

SONDERForschUNGSBereich 504 WORKING PAPER SERIES

\begin{tabular}{|c|c|c|}
\hline Nr. & $\begin{array}{l}\text { Author } \\
\end{array}$ & "Title \\
\hline 02-09 & Volker Stocké & $\begin{array}{l}\text { Soziale Erwünschtheit bei der Erfassung von } \\
\text { Einstellungen gegenüber Ausländern. Theoretische } \\
\text { Prognosen und deren empirische Überprüfung }\end{array}$ \\
\hline $02-08$ & $\begin{array}{l}\text { Volker Stocké } \\
\text { Bettina Langfeldt }\end{array}$ & $\begin{array}{l}\text { Ex-post Implementation with Interdependent } \\
\text { Valuations }\end{array}$ \\
\hline 02-07 & $\begin{array}{l}\text { Benny Moldovanu } \\
\text { Christian Ewerhart }\end{array}$ & A Stylized Model of the German UMTS Auction \\
\hline 02-06 & $\begin{array}{l}\text { Benny Moldovanu } \\
\text { Aner Sela }\end{array}$ & Contest Architecture \\
\hline 02-05 & $\begin{array}{l}\text { Benny Moldovanu } \\
\text { Christian Ewerhart }\end{array}$ & $\begin{array}{l}\text { The German UMTS Design: Insights From } \\
\text { Multi-Object Auction Theory }\end{array}$ \\
\hline $02-04$ & Alex Possajennikov & $\begin{array}{l}\text { Cooperative Prisoners and Aggressive Chickens: } \\
\text { Evolution of Strategies and Preferences in } 2 \times 2 \\
\text { Games }\end{array}$ \\
\hline $02-03$ & Alex Possajennikov & $\begin{array}{l}\text { Two-Speed Evolution of Strategies and Preferences } \\
\text { in Symmetric Games }\end{array}$ \\
\hline 02-02 & $\begin{array}{l}\text { Markus Ruder } \\
\text { Herbert Bless }\end{array}$ & $\begin{array}{l}\text { Mood and the reliance on the ease of retrieval } \\
\text { heuristic }\end{array}$ \\
\hline $01-52$ & $\begin{array}{l}\text { Martin Hellwig } \\
\text { Klaus M. Schmidt }\end{array}$ & $\begin{array}{l}\text { Discrete-Time Approximations of the } \\
\text { Holmström-Milgrom Brownian-Motion Model of } \\
\text { Intertemporal Incentive Provision }\end{array}$ \\
\hline $01-51$ & Martin Hellwig & $\begin{array}{l}\text { The Role of Boundary Solutions in Principal-Agent } \\
\text { Problems with Effort Costs Depending on Mean } \\
\text { Returns }\end{array}$ \\
\hline $01-50$ & Siegfried K. Berninghaus & $\begin{array}{l}\text { Evolution of conventions - some theoretical and } \\
\text { experimental aspects }\end{array}$ \\
\hline $01-49$ & Dezsö Szalay & Procurement with an Endogenous Type Distribution \\
\hline $01-48$ & $\begin{array}{l}\text { Martin Weber } \\
\text { Heiko Zuchel }\end{array}$ & $\begin{array}{l}\text { How Do Prior Outcomes Affect Risky Choice? } \\
\text { Further Evidence on the House-Money Effect and } \\
\text { Escalation of Commitment }\end{array}$ \\
\hline
\end{tabular}

SONDERFORSCHUNGSBereich 504 WORKING PAPER SERIES

\begin{tabular}{|c|c|c|}
\hline$\overline{\mathrm{Nr} .}$ & Author & Title \\
\hline $01-47$ & $\begin{array}{l}\text { Nikolaus Beck } \\
\text { Alfred Kieser }\end{array}$ & $\begin{array}{l}\text { The Complexity of Rule Systems, Experience, and } \\
\text { Organizational Learning }\end{array}$ \\
\hline $01-46$ & $\begin{array}{l}\text { Martin Schulz } \\
\text { Nikolaus Beck }\end{array}$ & Organizational Rules and Rule Histories \\
\hline $01-45$ & $\begin{array}{l}\text { Nikolaus Beck } \\
\text { Peter Walgenbach }\end{array}$ & $\begin{array}{l}\text { Formalization and ISO } 9000 \text { - Changes in the } \\
\text { German Machine Building Industry }\end{array}$ \\
\hline $01-44$ & $\begin{array}{l}\text { Anna Maffioletti } \\
\text { Ulrich Schmidt }\end{array}$ & $\begin{array}{l}\text { The Effect of Elicitation Methods on Ambiguity } \\
\text { Aversion: An Experimental Investigation }\end{array}$ \\
\hline $01-43$ & $\begin{array}{l}\text { Anna Maffioletti } \\
\text { Michele Santoni }\end{array}$ & $\begin{array}{l}\text { Do Trade Union Leaders Violate Subjective } \\
\text { Expected Utility?Some Insights from Experimental } \\
\text { Data }\end{array}$ \\
\hline $01-42$ & Axel Börsch-Supan & $\begin{array}{l}\text { Incentive Effects of Social Security Under an } \\
\text { Uncertain Disability Option }\end{array}$ \\
\hline $01-41$ & $\begin{array}{l}\text { Carmela Di Mauro } \\
\text { Anna Maffioletti }\end{array}$ & $\begin{array}{l}\text { Reaction to Uncertainty and Market } \\
\text { Mechanism:Experimental Evidence }\end{array}$ \\
\hline $01-40$ & $\begin{array}{l}\text { Marcel Normann } \\
\text { Thomas Langer }\end{array}$ & $\begin{array}{l}\text { Altersvorsorge, Konsumwunsch und mangelnde } \\
\text { Selbstdisziplin: Zur Relevanz deskriptiver Theorien } \\
\text { für die Gestaltung von Altersvorsorgeprodukten }\end{array}$ \\
\hline $01-39$ & Heiko Zuchel & What Drives the Disposition Effect? \\
\hline $01-38$ & Karl-Martin Ehrhart & $\begin{array}{l}\text { European Central Bank Operations: Experimental } \\
\text { Investigation of the Fixed Rate Tender }\end{array}$ \\
\hline $01-37$ & Karl-Martin Ehrhart & $\begin{array}{l}\text { European Central Bank Operations: Experimental } \\
\text { Investigation of Variable Rate Tenders }\end{array}$ \\
\hline $01-36$ & Karl-Martin Ehrhart & A Well-known Rationing Game \\
\hline $01-35$ & $\begin{array}{l}\text { Peter Albrecht } \\
\text { Raimond Maurer }\end{array}$ & $\begin{array}{l}\text { Self-Annuitization, Ruin Risk in Retirement and } \\
\text { Asset Allocation: The Annuity Benchmark }\end{array}$ \\
\hline $01-34$ & $\begin{array}{l}\text { Daniel Houser } \\
\text { Joachim Winter }\end{array}$ & $\begin{array}{l}\text { Time preference and decision rules in a price search } \\
\text { experiment }\end{array}$ \\
\hline
\end{tabular}




\begin{tabular}{|c|c|c|}
\hline Nr. & Author & Title \\
\hline $01-33$ & Christian Ewerhart & $\begin{array}{l}\text { Iterated Weak Dominance in Strictly Competitive } \\
\text { Games of Perfect Information }\end{array}$ \\
\hline $01-32$ & Christian Ewerhart & $\begin{array}{l}\text { THE K-DIMENSIONAL FIXED POINT } \\
\text { THEOREM OF PROVABILITY LOGIC }\end{array}$ \\
\hline $01-31$ & Christian Ewerhart & $\begin{array}{l}\text { A Decision-Theoretic Characterization of Iterated } \\
\text { Weak Dominance }\end{array}$ \\
\hline $01-30$ & Christian Ewerhart & $\begin{array}{l}\text { Heterogeneous Awareness and the Possibility of } \\
\text { Agreement }\end{array}$ \\
\hline $01-29$ & Christian Ewerhart & $\begin{array}{l}\text { An Example for a Game Involving Unawareness: } \\
\text { The Tragedy of Romeo and Juliet }\end{array}$ \\
\hline $01-28$ & Christian Ewerhart & $\begin{array}{l}\text { Backward Induction and the Game-Theoretic } \\
\text { Analysis of Chess }\end{array}$ \\
\hline $01-27$ & $\begin{array}{l}\text { Eric Igou } \\
\text { Herbert Bless }\end{array}$ & $\begin{array}{l}\text { About the Importance of Arguments, or: Order } \\
\text { Effects and Conversational Rules }\end{array}$ \\
\hline $01-26$ & $\begin{array}{l}\text { Heiko Zuchel } \\
\text { Martin Weber }\end{array}$ & The Disposition Effect and Momentum \\
\hline $01-25$ & Volker Stocké & $\begin{array}{l}\text { An Empirical Test of the Contingency Model for } \\
\text { the Explanation of Heuristic-Based Framing-Effects }\end{array}$ \\
\hline $01-24$ & Volker Stocké & $\begin{array}{l}\text { The Influence of Frequency Scales on the Response } \\
\text { Behavior. A Theoretical Model and its Empirical } \\
\text { Examination }\end{array}$ \\
\hline $01-23$ & Volker Stocké & $\begin{array}{l}\text { An Empirical Examination of Different } \\
\text { Interpretations of the Prospect Theoryś } \\
\text { Framing-Hypothesis }\end{array}$ \\
\hline $01-22$ & Volker Stocké & $\begin{array}{l}\text { Socially Desirable Response Behavior as Rational } \\
\text { Choice: The Case of Attitudes Towards Foreigners }\end{array}$ \\
\hline $01-21$ & $\begin{array}{l}\text { Phillipe Jehiel } \\
\text { Benny Moldovanu }\end{array}$ & License Auctions and Market Structure \\
\hline
\end{tabular}

\section{1-19 Arieh Gavious Benny Moldovanu Aner Sela}

01-18 Benny Moldovanu Karsten Fieseler Thomas Kittsteiner

\section{1-17 Raimond Maure} Martin Pitzer Steffen Sebastian

01-16 Martin Hellwig

01-15 Thomas Kittsteiner

01-14 Axel Börsch-Supan Agar Brugiavini

01-13 Thomas Langer

01-12 Peter Albrecht Raimond Maure Ulla Ruckpaul

01-11 Peter Albrecht Raimond Maurer

\section{1-10 Gyöngyi Bugàr} Raimond Maurer

01-09 Erich Kirchler Boris Maciejovsky Martin Weber
Bid Costs and Endogenous Bid Caps

Partnerships, Lemons and Efficient Trade

Construction of a Transaction Based Real Estate Index for the Paris Housing Market

The Impact of the Number of Participants on the Provision of a Public Good

Partnerships and Double Auctions with Interdependent Valuations

Savings: The Policy Debate in Europe

Fallstudie zum rationalen Entscheiden: Contingent Valuation und der Fall der Exxon Valdez

On the Risks of Stocks in the Long Run:A Probabilistic Approach Based on Measures of Shortfall Risk

Zum systematischen Vergleich von

Rentenversicherung und Fondsentnahmeplänen unter dem Aspekt des Kapitalverzehrrisikos - der Fall nach Steuern

International Equity Portfolios and Currency Hedging: The Viewpoint of German and Hungarian Investors

Framing Effects on Asset Markets - An Experimental Analysis -
SONDERFoRSCHUNGsBereich 504 WORKING PAPER SERIES

\begin{tabular}{|c|c|c|}
\hline$\overline{\mathrm{Nr} .}$ & Author & 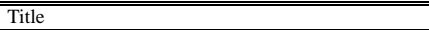 \\
\hline $01-08$ & $\begin{array}{l}\text { Axel Börsch-Supan } \\
\text { Alexander Ludwig } \\
\text { Joachim Winter }\end{array}$ & $\begin{array}{l}\text { Aging, pension reform, and capital flows: A } \\
\text { multi-country simulation model }\end{array}$ \\
\hline 01-07 & $\begin{array}{l}\text { Axel Börsch-Supan } \\
\text { Annette Reil-Held } \\
\text { Ralf Rodepeter } \\
\text { Reinhold Schnabel } \\
\text { Joachim Winter }\end{array}$ & The German Savings Puzzle \\
\hline 01-06 & Markus Glaser & $\begin{array}{l}\text { Behavioral Financial Engineering: eine Fallstudie } \\
\text { zum Rationalen Entscheiden }\end{array}$ \\
\hline 01-05 & $\begin{array}{l}\text { Peter Albrecht } \\
\text { Raimond Maurer }\end{array}$ & $\begin{array}{l}\text { Zum systematischen Vergleich von } \\
\text { Rentenversicherung und Fondsentnahmeplänen } \\
\text { unter dem Aspekt des Kapitalverzehrrisikos }\end{array}$ \\
\hline 01-04 & $\begin{array}{l}\text { Thomas Hintz } \\
\text { Dagmar Stahlberg } \\
\text { Stefan Schwarz }\end{array}$ & $\begin{array}{l}\text { Cognitive processes that work in hindsight: } \\
\text { Meta-cognitions or probability-matching? }\end{array}$ \\
\hline $01-03$ & $\begin{array}{l}\text { Dagmar Stahlberg } \\
\text { Sabine Sczesny } \\
\text { Friederike Braun }\end{array}$ & $\begin{array}{l}\text { Name your favourite musician: Effects of masculine } \\
\text { generics and of their alternatives in german }\end{array}$ \\
\hline $01-02$ & $\begin{array}{l}\text { Sabine Sczesny } \\
\text { Sandra Spreemann } \\
\text { Dagmar Stahlberg }\end{array}$ & $\begin{array}{l}\text { The influence of gender-stereotyped perfumes on } \\
\text { the attribution of leadership competence }\end{array}$ \\
\hline 01-01 & Geschäftsstelle & Jahresbericht 2000 \\
\hline $00-51$ & Angelika Eymann & Portfolio Choice and Knowledge \\
\hline $00-50$ & $\begin{array}{l}\text { Oliver Kirchkamp } \\
\text { Rosemarie Nagel }\end{array}$ & $\begin{array}{l}\text { Repeated Game Strategies in Local and Group } \\
\text { Prisoner's Dilemma }\end{array}$ \\
\hline $00-49$ & $\begin{array}{l}\text { Thomas Langer } \\
\text { Martin Weber }\end{array}$ & $\begin{array}{l}\text { The Impact of Feedback Frequency on Risk Taking: } \\
\text { How general is the Phenomenon? }\end{array}$ \\
\hline $00-48$ & $\begin{array}{l}\text { Niklas Siebenmorgen } \\
\text { Martin Weber }\end{array}$ & $\begin{array}{l}\text { The Influence of Different Investment Horizons on } \\
\text { Risk Behavior }\end{array}$ \\
\hline
\end{tabular}

SONDERFORSCHUNGSBereich 504 WORKING PAPER SERIES

\begin{tabular}{|c|c|c|}
\hline Nr. & $\begin{array}{l}\text { Author } \\
\end{array}$ & 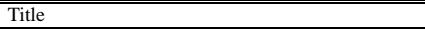 \\
\hline $00-47$ & $\begin{array}{l}\text { Roman Inderst } \\
\text { Christian Laux }\end{array}$ & Incentives in Internal Capital Markets \\
\hline $00-46$ & $\begin{array}{l}\text { Niklas Siebenmorgen } \\
\text { Martin Weber }\end{array}$ & $\begin{array}{l}\text { A Behavioral Approach to the Asset Allocation } \\
\text { Puzzle }\end{array}$ \\
\hline $00-45$ & $\begin{array}{l}\text { Thomas Langer } \\
\text { Rakesh Sarin } \\
\text { Martin Weber }\end{array}$ & $\begin{array}{l}\text { The Retrospective Evaluation of Payment } \\
\text { Sequences: Duration Neglect and } \\
\text { Peak-and-End-Effects }\end{array}$ \\
\hline $00-44$ & Axel Börsch-Supan & $\begin{array}{l}\text { Soziale Sicherung: Herausforderungen an der } \\
\text { Jahrhundertwende }\end{array}$ \\
\hline $00-43$ & $\begin{array}{l}\text { Rolf Elgeti } \\
\text { Raimond Maurer }\end{array}$ & $\begin{array}{l}\text { Zur Quantifizierung der Risikoprämien deutscher } \\
\text { Versicherungsaktien im Kontext eines } \\
\text { Multifaktorenmodells }\end{array}$ \\
\hline $00-42$ & Martin Hellwig & $\begin{array}{l}\text { Nonlinear Incentive Contracting in Walrasian } \\
\text { Markets: A Cournot Approach }\end{array}$ \\
\hline $00-41$ & Tone Dieckmann & $\begin{array}{l}\text { A Dynamic Model of a Local Public Goods } \\
\text { Economy with Crowding }\end{array}$ \\
\hline $00-40$ & $\begin{array}{l}\text { Claudia Keser } \\
\text { Bodo Vogt }\end{array}$ & $\begin{array}{l}\text { Why do experimental subjects choose an } \\
\text { equilibrium which is neither risk nor payoff } \\
\text { dominant }\end{array}$ \\
\hline $00-39$ & $\begin{array}{l}\text { Christian Dustmann } \\
\text { Oliver Kirchkamp }\end{array}$ & $\begin{array}{l}\text { The Optimal Migration Duration and Activity } \\
\text { Choice after Re-migration }\end{array}$ \\
\hline $00-38$ & $\begin{array}{l}\text { Niklas Siebenmorgen } \\
\text { Elke U. Weber } \\
\text { Martin Weber }\end{array}$ & $\begin{array}{l}\text { Communicating Asset Risk: How the format of } \\
\text { historic volatility information affects risk } \\
\text { perception and investment decisions }\end{array}$ \\
\hline $00-37$ & Siegfried K. Berninghaus & $\begin{array}{l}\text { The impact of monopolistic wage setting on } \\
\text { innovation and market structure }\end{array}$ \\
\hline $00-36$ & $\begin{array}{l}\text { Siegfried K. Berninghaus } \\
\text { Karl-Martin Ehrhart }\end{array}$ & $\begin{array}{l}\text { Coordination and information: Recent experimental } \\
\text { evidence }\end{array}$ \\
\hline $00-35$ & $\begin{array}{l}\text { Carlo Kraemer } \\
\text { Markus Nöth } \\
\text { Martin Weber }\end{array}$ & $\begin{array}{l}\text { Information Aggregation with Costly Information } \\
\text { and Random Ordering: Experimental Evidence }\end{array}$ \\
\hline
\end{tabular}




\begin{tabular}{|c|c|c|}
\hline Nr. & Author & Title \\
\hline $00-34$ & $\begin{array}{l}\text { Markus Nöth } \\
\text { Martin Weber }\end{array}$ & $\begin{array}{l}\text { Information Aggregation with Random Ordering: } \\
\text { Cascades and Overconfidence }\end{array}$ \\
\hline $00-33$ & $\begin{array}{l}\text { Tone Dieckmann } \\
\text { Ulrich Schwalbe }\end{array}$ & Dynamic Coalition Formation and the Core \\
\hline $00-32$ & Martin Hellwig & $\begin{array}{l}\text { Corporate Governance and the Financing of } \\
\text { Investment for Structural Change }\end{array}$ \\
\hline $00-31$ & $\begin{array}{l}\text { Peter Albrecht } \\
\text { Thorsten Göbel }\end{array}$ & $\begin{array}{l}\text { Rentenversicherung versus Fondsentnahmepläne, } \\
\text { oder: Wie groß ist die Gefahr, den Verzehr des } \\
\text { eigenen Vermögens zu überleben? }\end{array}$ \\
\hline $00-30$ & $\begin{array}{l}\text { Roman Inderst } \\
\text { Holger M. Müller } \\
\text { Karl Wärneryd }\end{array}$ & Influence Costs and Hierarchy \\
\hline $00-29$ & Dezsö Szalay & Optimal Delegation \\
\hline $00-28$ & Dezsö Szalay & Financial Contracting, R\&D and Growth \\
\hline $00-27$ & Axel Börsch-Supan & $\begin{array}{l}\text { Rentabilitätsvergleiche im Umlage- und } \\
\text { Kapitaldeckungsverfahren: Konzepte, empirische } \\
\text { Ergebnisse, sozialpolitische Konsequenzen }\end{array}$ \\
\hline $00-26$ & $\begin{array}{l}\text { Axel Börsch-Supan } \\
\text { Annette Reil-Held }\end{array}$ & $\begin{array}{l}\text { How much is transfer and how much insurance in a } \\
\text { pay-as-you-go system? The German Case. }\end{array}$ \\
\hline $00-25$ & Axel Börsch-Supan & $\begin{array}{l}\text { Rentenreform und die Bereitschaft zur } \\
\text { Eigenvorsorge: Umfrageergebnisse in Deutschland }\end{array}$ \\
\hline $00-24$ & Christian Ewerhart & $\begin{array}{l}\text { Chess-like games are dominancesolvable in at most } \\
\text { two steps }\end{array}$ \\
\hline $00-23$ & Christian Ewerhart & An Alternative Proof of Marshallś Rule \\
\hline $00-22$ & Christian Ewerhart & $\begin{array}{l}\text { Market Risks, Internal Models, and Optimal } \\
\text { Regulation: Does Backtesting Induce Banks to } \\
\text { Report Their True Risks? }\end{array}$ \\
\hline $00-21$ & Axel Börsch-Supan & A Blue Print for Germany's Pension Reform \\
\hline $00-$ & Axel Börsch-Supan & ata and Research on Retirement in Germany \\
\hline
\end{tabular}

\begin{tabular}{|c|c|c|}
\hline $\mathrm{Nr}$. & Author & Title \\
\hline $00-19$ & $\begin{array}{l}\text { Henning Plessner } \\
\text { Tilmann Betsch }\end{array}$ & $\begin{array}{l}\text { Sequential effects in important sport-decisions: The } \\
\text { case of penalties in soccer }\end{array}$ \\
\hline $00-18$ & $\begin{array}{l}\text { Susanne Haberstroh } \\
\text { Ulrich Kühnen } \\
\text { Daphna Oyserman } \\
\text { Norbert Schwarz }\end{array}$ & $\begin{array}{l}\text { Is the interdependent self a better communicator } \\
\text { than the independent self? Self-construal and the } \\
\text { observation of conversational norms }\end{array}$ \\
\hline $00-17$ & $\begin{array}{l}\text { Tilmann Betsch } \\
\text { Susanne Haberstroh } \\
\text { Connie Höhle }\end{array}$ & $\begin{array}{l}\text { Explaining and Predicting Routinized Decision } \\
\text { Making: A Review of Theories }\end{array}$ \\
\hline $00-16$ & $\begin{array}{l}\text { Susanne Haberstroh } \\
\text { Tilmann Betsch } \\
\text { Henk Aarts }\end{array}$ & $\begin{array}{l}\text { When guessing is better than thinking: Multiple } \\
\text { bases for frequency judgments }\end{array}$ \\
\hline $00-15$ & $\begin{array}{l}\text { Axel Börsch-Supan } \\
\text { Angelika Eymann }\end{array}$ & Household Portfolios in Germany \\
\hline $00-14$ & Annette Reil-Held & $\begin{array}{l}\text { Einkommen und Sterblichkeit in Deutschland: } \\
\text { Leben Reiche länger? }\end{array}$ \\
\hline $00-13$ & $\begin{array}{l}\text { Nikolaus Beck } \\
\text { Martin Schulz }\end{array}$ & $\begin{array}{l}\text { Comparing Rule Histories in the U.S. and in } \\
\text { Germany: Searching for General Principles of } \\
\text { Organizational Rules }\end{array}$ \\
\hline $00-12$ & Volker Stocké & $\begin{array}{l}\text { Framing ist nicht gleich Framing. Eine Typologie } \\
\text { unterschiedlicher Framing-Effekte und Theorien zu } \\
\text { deren Erklärung }\end{array}$ \\
\hline $00-11$ & $\begin{array}{l}\text { Oliver Kirchkamp } \\
\text { Rosemarie Nagel }\end{array}$ & $\begin{array}{l}\text { Local and Group Interaction in Prisoners } \\
\text { Dilemmas }\end{array}$ \\
\hline $00-10$ & $\begin{array}{l}\text { Oliver Kirchkamp } \\
\text { Benny Moldovanu }\end{array}$ & $\begin{array}{l}\text { An experimental analysis of auctions with } \\
\text { interdependent valuations }\end{array}$ \\
\hline 00-09 & Oliver Kirchkamp & $\begin{array}{l}\text { WWW Experiments for Economists, a Technical } \\
\text { Introduction }\end{array}$ \\
\hline $00-08$ & $\begin{array}{l}\text { Alain Chateauneuf } \\
\text { Alain Chateauneuf }\end{array}$ & $\begin{array}{l}\text { Organizational Learning through Rule Adaptation: } \\
\text { From the Behavioral Theory to Transactive } \\
\text { Organizational Learning }\end{array}$ \\
\hline
\end{tabular}

SONDERFORSCHUNGSBereich 504 WORKING PAPER SERIES

\begin{tabular}{|c|c|c|}
\hline Nr. & $\begin{array}{l}\text { Author } \\
\end{array}$ & $\begin{array}{l}\text { Title } \\
\end{array}$ \\
\hline 00-07 & $\begin{array}{l}\text { Raimond Maurer } \\
\text { Steffen Sebastian }\end{array}$ & $\begin{array}{l}\text { Inflation Risk Analysis of European Real Estate } \\
\text { Securities }\end{array}$ \\
\hline 00-06 & Martin Hellwig & $\begin{array}{l}\text { Costly State Verification: The Choice Between Ex } \\
\text { Ante and Ex Post Verification Mechanisms }\end{array}$ \\
\hline 00-05 & $\begin{array}{l}\text { Peter Albrecht } \\
\text { Raimond Maurer }\end{array}$ & $\begin{array}{l}100 \% \text { Aktien zur Altersvorsorge - Über die } \\
\text { Langfristrisiken einer Aktienanlage }\end{array}$ \\
\hline 00-04 & Douglas Gale & $\begin{array}{l}\text { Aging and the Pension Crisis: Flexibilization } \\
\text { through Capital Markets }\end{array}$ \\
\hline 00-03 & Axel Börsch-Supan & Data and Research on Saving in Germany \\
\hline 00-02 & $\begin{array}{l}\text { Raimond Maurer } \\
\text { Alexander Mertz }\end{array}$ & $\begin{array}{l}\text { Internationale Diversifikation von Aktien- und } \\
\text { Anleiheportfolios aus der Perspektive deutscher } \\
\text { Investoren }\end{array}$ \\
\hline 00-01 & Office SFB504 & Jahresbericht 1999 \\
\hline 99-89 & $\begin{array}{l}\text { Holger M. Müller } \\
\text { Roman Inderst }\end{array}$ & $\begin{array}{l}\text { Project Bundling, Liquidity Spillovers, and Capital } \\
\text { Market Discipline }\end{array}$ \\
\hline 99-88 & $\begin{array}{l}\text { Raimond Maurer } \\
\text { Gyöngyi Bugàr }\end{array}$ & $\begin{array}{l}\text { Efficient Risk Reducing Strategies by International } \\
\text { Diversification: Evidence from a Central European } \\
\text { Emerging Market }\end{array}$ \\
\hline $99-87$ & $\begin{array}{l}\text { Berit Ernst } \\
\text { Alfred Kieser }\end{array}$ & $\begin{array}{l}\text { In Search of Explanations for the Consulting } \\
\text { Explosion. A Critical Perspective on Managers' } \\
\text { Decisions to Contract a Consultancy }\end{array}$ \\
\hline 99-86 & $\begin{array}{l}\text { Martin Hellwig } \\
\text { Andreas Irmen }\end{array}$ & $\begin{array}{l}\text { Wage Growth, Productivity Growth, and the } \\
\text { Evolution of Employment }\end{array}$ \\
\hline 99-85 & $\begin{array}{l}\text { Siegfried K. Berninghaus } \\
\text { Werner Gueth } \\
\text { Claudia Keser }\end{array}$ & $\begin{array}{l}\text { Decentralized or Collective Bargaining in a Strategy } \\
\text { Experiment }\end{array}$ \\
\hline $99-84$ & Jan Vleugels & $\begin{array}{l}\text { Bidding Against an Unknown Number of } \\
\text { Competitors With Affiliated Information }\end{array}$ \\
\hline $99-83$ & $\begin{array}{l}\text { Stefan Schwarz } \\
\text { Ulf-Dietrich Reips }\end{array}$ & Drop-out wegen JavaScript: \\
\hline
\end{tabular}

SONDERFORSCHUNGSBereich 504 WORKING PAPER SERIES

\begin{tabular}{|c|c|c|}
\hline Nr. & $\begin{array}{l}\text { Author } \\
\end{array}$ & 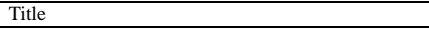 \\
\hline $99-82$ & $\begin{array}{l}\text { Holger M. Müller } \\
\text { Karl Wärneryd }\end{array}$ & $\begin{array}{l}\text { Inside vs Outside Ownership - A Political Theory of } \\
\text { the Firm }\end{array}$ \\
\hline $99-81$ & $\begin{array}{l}\text { Ralf Rodepeter } \\
\text { Joachim Winter }\end{array}$ & Rules of thumb in life-cycle savings models \\
\hline $99-80$ & $\begin{array}{l}\text { Michael Adam } \\
\text { Raimond Maurer }\end{array}$ & $\begin{array}{l}\text { Risk Value Analysis of Covered Short Call and } \\
\text { Protective Put Portfolio Strategies }\end{array}$ \\
\hline $99-79$ & Peter Albrecht & $\begin{array}{l}\text { Rendite oder Sicherheit in der Altersversorgung - } \\
\text { unvereinbare Gegensätze? }\end{array}$ \\
\hline $99-78$ & Karsten Fieseler & $\begin{array}{l}\text { The Efficient Bilateral Trade of an Indivisible } \\
\text { Good: Successively Arriving Information }\end{array}$ \\
\hline $99-77$ & Karsten Fieseler & Optimal Leasing Durations: Options for Extension \\
\hline $99-76$ & $\begin{array}{l}\text { Peter Albrecht } \\
\text { Raimond Maurer }\end{array}$ & $\begin{array}{l}\text { Zur Bedeutung einer Ausfallbedrohtheit von } \\
\text { Versicherungskontrakten - ein Beitrag zur } \\
\text { Behavioral Insurance }\end{array}$ \\
\hline $99-75$ & $\begin{array}{l}\text { Benny Moldovanu } \\
\text { Aner Sela }\end{array}$ & The Optimal Allocation of Prizes in Contests \\
\hline $99-74$ & $\begin{array}{l}\text { Phillipe Jehiel } \\
\text { Benny Moldovanu }\end{array}$ & Efficient Design with Interdependent Valuations \\
\hline $99-73$ & $\begin{array}{l}\text { Phillipe Jehiel } \\
\text { Benny Moldovanu }\end{array}$ & $\begin{array}{l}\text { A Note on Revenue Maximization and Efficiency in } \\
\text { Multi-Object Auctions }\end{array}$ \\
\hline $99-72$ & $\begin{array}{l}\text { Eva Brit Kramer } \\
\text { Martin Weber }\end{array}$ & $\begin{array}{l}\text { Über kurz oder lang - Spielt der Anlagehorizont } \\
\text { eine berechtigte Rolle bei der Beurteilung von } \\
\text { Investments? }\end{array}$ \\
\hline $99-71$ & $\begin{array}{l}\text { Karsten Fieseler } \\
\text { Thomas Kittsteiner } \\
\text { Benny Moldovanu }\end{array}$ & Partnerships, Lemons and Efficient Trade \\
\hline $99-70$ & $\begin{array}{l}\text { Dagmar Stahlberg } \\
\text { Sabine Sczesny } \\
\text { Stefan Schwarz }\end{array}$ & $\begin{array}{l}\text { Exculpating Victims and the Reversal of Hindsight } \\
\text { Bias }\end{array}$ \\
\hline
\end{tabular}




\begin{tabular}{|c|c|c|}
\hline Nr. & Author & "Title \\
\hline $99-69$ & $\begin{array}{l}\text { Karl-Martin Ehrhart } \\
\text { Claudia Keser }\end{array}$ & Mobility and cooperation: on the run \\
\hline $99-68$ & $\begin{array}{l}\text { Roman Inderst } \\
\text { Holger M. Müller }\end{array}$ & $\begin{array}{l}\text { Delegation of Control Rights, Ownership } \\
\text { Concentration, and the Decline of External Finance }\end{array}$ \\
\hline $99-67$ & $\begin{array}{l}\text { Eric Igou } \\
\text { Herbert Bless } \\
\text { Michaela Wänke }\end{array}$ & $\begin{array}{l}\text { Ursachen der Verwässerung oder: } \\
\text { Konversationslogische Aspekte des } \\
\text { "Dilution-Effektes" }\end{array}$ \\
\hline $99-66$ & $\begin{array}{l}\text { Stefan Schwarz } \\
\text { Dagmar Stahlberg }\end{array}$ & $\begin{array}{l}\text { Auswirkungen des Hindsight Bias auf ökonomische } \\
\text { Entscheidungen }\end{array}$ \\
\hline $99-65$ & $\begin{array}{l}\text { Susanne Abele } \\
\text { Karl-Martin Ehrhart }\end{array}$ & $\begin{array}{l}\text { Why Timing Matters: Differential Effects of } \\
\text { Uncertainty about the Outcome of Past versus } \\
\text { Current Events }\end{array}$ \\
\hline $99-64$ & $\begin{array}{l}\text { Thomas Langer } \\
\text { Martin Weber }\end{array}$ & $\begin{array}{l}\text { Prospect-Theory, Mental Accounting and } \\
\text { Differences in Aggregated and Segregated } \\
\text { Evaluation of Lottery Portfolios }\end{array}$ \\
\hline $99-63$ & $\begin{array}{l}\text { Andreas Laschke } \\
\text { Martin Weber }\end{array}$ & $\begin{array}{l}\text { Der "Overconfidence Bias" und seine } \\
\text { Konsequenzen in Finanzmärkten }\end{array}$ \\
\hline $99-62$ & $\begin{array}{l}\text { Nikolaus Beck } \\
\text { Peter Walgenbach }\end{array}$ & $\begin{array}{l}\text { From Statistical Quality Control, over Quality } \\
\text { Systems to Total Quality Management - The } \\
\text { Institutionalization of a New Management } \\
\text { Approach }\end{array}$ \\
\hline $99-61$ & $\begin{array}{l}\text { Paul Povel } \\
\text { Michael Raith }\end{array}$ & $\begin{array}{l}\text { Endogenous Debt Contracts With Undistorted } \\
\text { Incentives }\end{array}$ \\
\hline $99-60$ & $\begin{array}{l}\text { Nikolaus Beck } \\
\text { Alfred Kieser }\end{array}$ & $\begin{array}{l}\text { Unspectacular Organizational Change in Normal } \\
\text { Times: Rule Change as a Routine Activity }\end{array}$ \\
\hline $99-59$ & $\begin{array}{l}\text { Roman Inderst } \\
\text { Holger M. Müller }\end{array}$ & Why Peaches Must Circulate Longer than Lemons \\
\hline $99-58$ & Roman Inderst & $\begin{array}{l}\text { Bargaining with Sequential Buyers under } \\
\text { Incomplete Information }\end{array}$ \\
\hline $99-57$ & Roman Inderst & Bargaining with a Possibly Committed Seller \\
\hline
\end{tabular}

\begin{tabular}{|c|c|c|}
\hline Nr. & Author & $\begin{array}{l}\text { Title } \\
\end{array}$ \\
\hline $99-56$ & Roman Inderst & $\begin{array}{l}\text { Efficiency Wages under Adverse Selection and the } \\
\text { Role of Rigid Wages }\end{array}$ \\
\hline $99-55$ & Daniel Probst & Evolution, Automata and Repeated Games \\
\hline $99-54$ & $\begin{array}{l}\text { Christian Laux } \\
\text { Daniel Probst }\end{array}$ & $\begin{array}{l}\text { The Ambiguous Effects of Rankings: Strategically } \\
\text { Biased Forecasting by Advisers }\end{array}$ \\
\hline $99-53$ & $\begin{array}{l}\text { Martin Hellwig } \\
\text { Andreas Irmen }\end{array}$ & $\begin{array}{l}\text { Endogenous Technical Change in a Competitive } \\
\text { Economy }\end{array}$ \\
\hline 99-52 & $\begin{array}{l}\text { Roman Inderst } \\
\text { Holger M. Müller }\end{array}$ & Competitive Search Markets with Adverse Selection \\
\hline $99-51$ & $\begin{array}{l}\text { Abdolkarim Sadrieh } \\
\text { Werner Gueth } \\
\text { Peter Hammerstein } \\
\text { Stevan Harnard } \\
\text { Ulrich Hoffrage } \\
\text { Bettina Kuon } \\
\text { Betrand R. Munier } \\
\text { Peter M. Todd } \\
\text { Massimo Warglien } \\
\text { Martin Weber }\end{array}$ & Is there evidence for an adaptive toolbox? \\
\hline $99-50$ & $\begin{array}{l}\text { Ulrich Hoffrage } \\
\text { Gerd Gigerenzer }\end{array}$ & How to Foster Diagnostic Insight in Experts \\
\hline $99-49$ & $\begin{array}{l}\text { Martin Lages } \\
\text { Ulrich Hoffrage } \\
\text { Gerd Gigerenzer }\end{array}$ & Intransitivity of fast and frugal heuristics \\
\hline 99-48 & $\begin{array}{l}\text { Axel Börsch-Supan } \\
\text { Joachim Winter }\end{array}$ & $\begin{array}{l}\text { Pension reform, savings behavior and corporate } \\
\text { governance }\end{array}$ \\
\hline $99-47$ & $\begin{array}{l}\text { Craig R. Fox } \\
\text { Martin Weber }\end{array}$ & $\begin{array}{l}\text { Ambiguity Aversion, Comparative Ignorance, and } \\
\text { the Role of Context }\end{array}$ \\
\hline $99-46$ & $\begin{array}{l}\text { Manfred Hassebrauck } \\
\text { Cornelia Vogt } \\
\text { Michael Diehl }\end{array}$ & $\begin{array}{l}\text { Der Einfluß von Prototypen auf die } \\
\text { Informationssuche bei Entscheidungen }\end{array}$ \\
\hline
\end{tabular}

SONDERForschUNGsBereich 504 WORKING PAPER SERIES

\begin{tabular}{|c|c|c|}
\hline Nr. & Author & $\begin{array}{l}\text { Title } \\
\end{array}$ \\
\hline $99-45$ & $\begin{array}{l}\text { Manfred Hassebrauck } \\
\text { Cornelia Vogt } \\
\text { Michael Diehl }\end{array}$ & $\begin{array}{l}\text { Das "prototype matching"-Modell des } \\
\text { Entscheidungsverhaltens: Der Einfluß kognitiver } \\
\text { Belastung, Zeitdruck und Stimmung }\end{array}$ \\
\hline $99-44$ & $\begin{array}{l}\text { Axel Börsch-Supan } \\
\text { Patrizia Tumbarello } \\
\text { Robert Palacios }\end{array}$ & $\begin{array}{l}\text { Pension systems in the Middle East and North } \\
\text { Africa: A window of opportunity }\end{array}$ \\
\hline $99-43$ & Reinhold Schnabel & $\begin{array}{l}\text { Vermögen und Ersparnis im Lebenszyklus in } \\
\text { Westdeutschland }\end{array}$ \\
\hline $99-42$ & Reinhold Schnabel & $\begin{array}{l}\text { The Declining Participation in the German } \\
\text { PAYG-Pension System }\end{array}$ \\
\hline $99-41$ & Reinhold Schnabel & $\begin{array}{l}\text { Social Security Reform and Intergenerational } \\
\text { Redistribution in Germany }\end{array}$ \\
\hline $99-40$ & Reinhold Schnabel & $\begin{array}{l}\text { The Golden Years of Social Security - Life-cycle } \\
\text { Income, Pensions and Savings in Germany }\end{array}$ \\
\hline $99-39$ & $\begin{array}{l}\text { Stefan Schwarz } \\
\text { Sabine Sczesny } \\
\text { Dagmar Stahlberg }\end{array}$ & $\begin{array}{l}\text { Der Hindsight Bias bei gustatorischen } \\
\text { Entscheidungen }\end{array}$ \\
\hline $99-38$ & $\begin{array}{l}\text { Axel Börsch-Supan } \\
\text { Annette Reil-Held }\end{array}$ & Family Resources in Retirement. Germany \\
\hline $99-37$ & $\begin{array}{l}\text { Axel Börsch-Supan } \\
\text { Rob Euwals } \\
\text { Angelika Eymann }\end{array}$ & $\begin{array}{l}\text { Portfolio Choice with Behavioral Decision } \\
\text { Mechanisms }\end{array}$ \\
\hline $99-36$ & Axel Börsch-Supan & $\begin{array}{l}\text { Template for International Savings Comparisons } \\
\text { Project }\end{array}$ \\
\hline $99-35$ & $\begin{array}{l}\text { Stefan Schwarz } \\
\text { Dagmar Stahlberg }\end{array}$ & $\begin{array}{l}\text { Hindsight Bias: The Role of Perfect Memory and } \\
\text { Meta-Cognitions }\end{array}$ \\
\hline 99-34 & $\begin{array}{l}\text { Dagmar Stahlberg } \\
\text { Stefan Schwarz }\end{array}$ & $\begin{array}{l}\text { Would I Have Known It All Along if I Would Hate } \\
\text { to Know It? The Hindsight Bias in Situations of }\end{array}$ \\
\hline
\end{tabular}

SONDERForschungsBereich 504 WORKING PAPER SERIES

\begin{tabular}{|c|c|c|}
\hline Nr. & $\begin{array}{l}\text { Author } \\
\end{array}$ & Title \\
\hline $99-33$ & $\begin{array}{l}\text { Ulrich Hoffrage } \\
\text { Ralph Hertwig } \\
\text { Gerd Gigerenzer }\end{array}$ & $\begin{array}{l}\text { Hindsight Bias: A By-product of Knowledge } \\
\text { Updating }\end{array}$ \\
\hline $99-32$ & $\begin{array}{l}\text { Ralph Hertwig } \\
\text { Ulrich Hoffrage }\end{array}$ & $\begin{array}{l}\text { Begrenzte Rationalität: Die Alternative zu } \\
\text { Laplace'schen und schlechter Software }\end{array}$ \\
\hline $99-31$ & $\begin{array}{l}\text { Raimond Maurer } \\
\text { Ulrich Hoffrage }\end{array}$ & $\begin{array}{l}\text { An Expected Utility Approach to Probabilistic } \\
\text { Insurance: A Comment on Wakker, Thaler and } \\
\text { Tversky (1997) }\end{array}$ \\
\hline $99-30$ & $\begin{array}{l}\text { Henning Plessner } \\
\text { Susanne Haberstroh } \\
\text { Tilmann Betsch }\end{array}$ & $\begin{array}{l}\text { The effects of affect-based attitudes on judgment } \\
\text { and decision making }\end{array}$ \\
\hline $99-29$ & $\begin{array}{l}\text { Tilmann Betsch } \\
\text { Andreas Glöckner } \\
\text { Susanne Haberstroh }\end{array}$ & $\begin{array}{l}\text { A Micro-World Simulation to Study Routine } \\
\text { Maintenance and Deviation in Repeated Decision } \\
\text { Making }\end{array}$ \\
\hline $99-28$ & $\begin{array}{l}\text { Jan Walliser } \\
\text { Joachim Winter }\end{array}$ & $\begin{array}{l}\text { Tax incentives, bequest motives and the demand for } \\
\text { life insurance: evidence from Germany }\end{array}$ \\
\hline $99-27$ & Joachim Winter & $\begin{array}{l}\text { Ökonometrische Analyse diskreter dynamischer } \\
\text { Entscheidungsprozesse }\end{array}$ \\
\hline $99-26$ & $\begin{array}{l}\text { Gerd Bohner } \\
\text { Dagmar Stahlberg } \\
\text { Dieter Frey }\end{array}$ & Einstellungen \\
\hline $99-25$ & $\begin{array}{l}\text { Ulrich Hoffrage } \\
\text { Martin Weber } \\
\text { Ralph Hertwig } \\
\text { Valerie Chase }\end{array}$ & $\begin{array}{l}\text { How to keep children save in traffic: Find the } \\
\text { daredevils while they are young. }\end{array}$ \\
\hline $99-24$ & $\begin{array}{l}\text { Elke Kurz } \\
\text { Gerd Gigerenzer } \\
\text { Ulrich Hoffrage }\end{array}$ & $\begin{array}{l}\text { Representations of uncertainty and change: Three } \\
\text { case studies with experts }\end{array}$ \\
\hline $99-23$ & $\begin{array}{l}\text { Stefan Krauss } \\
\text { Laura Martignon } \\
\text { Ulrich Hoffrage }\end{array}$ & Simplifying Bayesian Inference: The General Case \\
\hline
\end{tabular}




\begin{tabular}{|c|c|c|}
\hline Nr. & Author & Title \\
\hline $99-22$ & $\begin{array}{l}\text { Ulrich Hoffrage } \\
\text { Ralph Hertwig }\end{array}$ & $\begin{array}{l}\text { Hindsight Bias: A Price Worth Paying for Fast and } \\
\text { Frugal Memory }\end{array}$ \\
\hline $99-21$ & Ulrich Hoffrage & $\begin{array}{l}\text { Irren ist wahrscheinlich. Medizinische Experten } \\
\text { und Laien bewerten Risiken oft falsch. }\end{array}$ \\
\hline $99-20$ & $\begin{array}{l}\text { Claudia Keser } \\
\text { Jean-Louis Rulliére } \\
\text { Marie-Claire Villeval }\end{array}$ & $\begin{array}{l}\text { Union Bargaining Strength as a Public Good: } \\
\text { Experimental Evidence }\end{array}$ \\
\hline $99-19$ & $\begin{array}{l}\text { Rüdiger F. Pohl } \\
\text { Dagmar Stahlberg } \\
\text { Dieter Frey }\end{array}$ & $\begin{array}{l}\text { I'm not trying to impress you, but I surely knew it } \\
\text { all along! Self-presentation and hindsight bias }\end{array}$ \\
\hline $99-18$ & $\begin{array}{l}\text { Dagmar Stahlberg } \\
\text { Lars-Eric Petersen } \\
\text { Dirk Dauenheimer }\end{array}$ & $\begin{array}{l}\text { Preferences for and Evaluation on Self-Relevant } \\
\text { Information Depending on the Elaboration of the } \\
\text { Self-Schemata Involved }\end{array}$ \\
\hline $99-17$ & Rob Euwals & $\begin{array}{l}\text { Do mandatory pensions decrease household } \\
\text { savings? Evidence for the Netherlands. }\end{array}$ \\
\hline $99-16$ & Roman Inderst & $\begin{array}{l}\text { A Note on the Strategic Foundation of Competitive } \\
\text { Equilibrium in Buyer Markets }\end{array}$ \\
\hline $99-15$ & $\begin{array}{l}\text { Michael Adam } \\
\text { Raimond Maurer }\end{array}$ & $\begin{array}{l}\text { An Empirical Test of Risk-Adjusted Performance of } \\
\text { Call Option Writing and Put Option Buying } \\
\text { Hedge-Strategies }\end{array}$ \\
\hline $99-14$ & $\begin{array}{l}\text { Annette Reil-Held } \\
\text { Reinhold Schnabel }\end{array}$ & $\begin{array}{l}\text { Vom Arbeitsmarkt in den Ruhestand: Die } \\
\text { Einkommen deutscher Rentner und Rentnerinnen }\end{array}$ \\
\hline $99-13$ & Peter Walgenbach & $\begin{array}{l}\text { Das Konzept der Vertrauensorganisation - Eine } \\
\text { theoriegeleitete Betrachtung }\end{array}$ \\
\hline $99-12$ & $\begin{array}{l}\text { Herbert Bless } \\
\text { Michaela Wänke }\end{array}$ & $\begin{array}{l}\text { Can the same information be typical and atypical? } \\
\text { How perceived typicality moderates assimilation } \\
\text { and contrast in evaluative judgements }\end{array}$ \\
\hline $99-11$ & $\begin{array}{l}\text { Eric Igou } \\
\text { Herbert Bless } \\
\text { Wolfram Schenck }\end{array}$ & $\begin{array}{l}\text { Stärkere Framing Effekte durch mehr Nachdenken? } \\
\text { Einflüsse der Bearbeitungszeit auf Lösungen des } \\
\text { "Asian-disease"-Problems }\end{array}$ \\
\hline
\end{tabular}

\begin{tabular}{|c|c|c|}
\hline Nr. & $\begin{array}{l}\text { Author } \\
\end{array}$ & 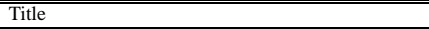 \\
\hline $99-10$ & $\begin{array}{l}\text { Dirk Dauenheimer } \\
\text { Dagmar Stahlberg } \\
\text { Sandra Spreemann } \\
\text { Constantine Sedikides }\end{array}$ & $\begin{array}{l}\text { Self-Enhancement, Self-Verification, or } \\
\text { Self-Assessment? The Intricate Role of Trait } \\
\text { Modifiability in the Self-Evaluation Process }\end{array}$ \\
\hline 99-09 & $\begin{array}{l}\text { Cornelia Hegele } \\
\text { Peter Walgenbach }\end{array}$ & $\begin{array}{l}\text { Was kann der Apfel von der Birne lernen, oder } \\
\text { wozu brauchen Unternehmen Benchmarking? }\end{array}$ \\
\hline 99-08 & Michaela Wänke & $\begin{array}{l}\text { Assimilation and Contrast as a Function of the } \\
\text { direction of Comparison }\end{array}$ \\
\hline $99-07$ & Michael Woywode & $\begin{array}{l}\text { Ein lerntheoretisches Modell zur Erklärung der } \\
\text { Unternehmensent-wicklung }\end{array}$ \\
\hline $99-06$ & $\begin{array}{l}\text { Tilmann Betsch } \\
\text { Susanne Haberstroh } \\
\text { Andreas Glöckner } \\
\text { Klaus Fiedler }\end{array}$ & $\begin{array}{l}\text { The Pros and Cons of Expertise: Routine Strength } \\
\text { and Adaptation in Recurrent Acquisition and } \\
\text { Disposal Decisions }\end{array}$ \\
\hline 99-05 & Ulrich Koch & $\begin{array}{l}\text { Regeländerungsprozesse und organisatorisches } \\
\text { Lernen: Zum Übergang individueller Erfahrungen } \\
\text { in eine organisationale Wissensbasis }\end{array}$ \\
\hline $99-04$ & $\begin{array}{l}\text { Alfred Kieser } \\
\text { Ulrich Koch } \\
\text { Michael Woywode }\end{array}$ & Wie man Bürokratien das Lernen beibringt \\
\hline $99-03$ & Joachim Winter & $\begin{array}{l}\text { Strukturelle ökonometrische Verfahren zur Analyse } \\
\text { von Renteneintrittsentscheidungen }\end{array}$ \\
\hline $99-02$ & $\begin{array}{l}\text { Axel Börsch-Supan } \\
\text { Annette Reil-Held } \\
\text { Ralf Rodepeter } \\
\text { Reinhold Schnabel } \\
\text { Joachim Winter }\end{array}$ & $\begin{array}{l}\text { Ersparnisbildung in Deutschland: Meßkonzepte und } \\
\text { Ergebnisse auf Basis der EVS }\end{array}$ \\
\hline 99-01 & Office SFB504 & Jahresbericht 1998 \\
\hline $98-61$ & $\begin{array}{l}\text { Siegfried K. Berninghaus } \\
\text { Karl-Martin Ehrhart }\end{array}$ & $\begin{array}{l}\text { Long-run Evolution of Local Interaction Structures } \\
\text { in Games }\end{array}$ \\
\hline
\end{tabular}

SONDERFORSCHUNGSBereich 504 WORKING PAPER SERIES

\begin{tabular}{|c|c|c|}
\hline Nr. & $\begin{array}{l}\text { Author } \\
\end{array}$ & "Title \\
\hline $98-60$ & $\begin{array}{l}\text { Isabel Gödde } \\
\text { Reinhold Schnabel }\end{array}$ & $\begin{array}{l}\text { Does Family Background Matter? - Returns to } \\
\text { Education and Family Characteristics in Germany }\end{array}$ \\
\hline $98-59$ & Holger M. Müller & Why Tender Offers Should be Financed with Debt \\
\hline $98-58$ & $\begin{array}{l}\text { Ralf Rodepeter } \\
\text { Joachim Winter }\end{array}$ & $\begin{array}{l}\text { Savings decisions under life-time and earnings } \\
\text { uncertainty: }\end{array}$ \\
\hline $98-57$ & $\begin{array}{l}\text { Thomas Langer } \\
\text { Martin Weber }\end{array}$ & Entscheidungsanalyse \\
\hline $98-56$ & Reinhold Schnabel & $\begin{array}{l}\text { Rates of Return of the German Pay-As-You-Go } \\
\text { Pension System }\end{array}$ \\
\hline $98-55$ & $\begin{array}{l}\text { Raimond Maurer } \\
\text { Steffen Sebastian }\end{array}$ & $\begin{array}{l}\text { Immobilienfonds und } \\
\text { Immobilienaktiengesellschaften als } \\
\text { finanzwirtschaftliche Substitute für } \\
\text { Immobiliendirektanlagen }\end{array}$ \\
\hline $98-54$ & $\begin{array}{l}\text { Michaela Wänke } \\
\text { Herbert Bless } \\
\text { Eric Igou }\end{array}$ & $\begin{array}{l}\text { Next to a star: Paling, shining or both? Turning } \\
\text { inter-exemplar contrast into inter-exemplar } \\
\text { assimilation }\end{array}$ \\
\hline $98-53$ & $\begin{array}{l}\text { Gerd Gigerenzer } \\
\text { Laura Martignon } \\
\text { Ulrich Hoffrage } \\
\text { Joerg Rieskamp } \\
\text { Jean Czerlinski } \\
\text { Dan G. Goldstein }\end{array}$ & One-reason decision making. \\
\hline $98-52$ & $\begin{array}{l}\text { Gerd Gigerenzer } \\
\text { Ralph Hertwig } \\
\text { Ulrich Hoffrage } \\
\text { Peter Sedlmeier }\end{array}$ & Cognitive illusions reconsidered \\
\hline $98-51$ & $\begin{array}{l}\text { Gerd Gigerenzer } \\
\text { Ulrich Hoffrage }\end{array}$ & $\begin{array}{l}\text { Overcoming Difficulties in Bayesian Reasoning: A } \\
\text { Reply to Lewis \& Keren and Mellers \& McGraw }\end{array}$ \\
\hline $98-50$ & Roman Inderst & Signaling in a Search Market \\
\hline $98-49$ & $\begin{array}{l}\text { Paul Povel } \\
\text { Michael Raith }\end{array}$ & $\begin{array}{l}\text { Liquidity Constraints, Production Costs and Output } \\
\text { Decisions }\end{array}$ \\
\hline
\end{tabular}

SONDERFORSCHUNGSBereich 504 WORKING PAPER SERIES

\begin{tabular}{|c|c|c|}
\hline$\overline{\mathrm{Nr} .}$ & Author & Title \\
\hline $98-48$ & Joachim Winter & $\begin{array}{l}\text { Does Firms' Financial Status Affect Plant-Level } \\
\text { Investment and Exit Decision }\end{array}$ \\
\hline $98-47$ & $\begin{array}{l}\text { Michele Bernasconi } \\
\text { Oliver Kirchkamp }\end{array}$ & $\begin{array}{l}\text { Why monetary policy matters - An experimental } \\
\text { study of saving, inflation and monetary policies in } \\
\text { an overlapping generations model }\end{array}$ \\
\hline $98-46$ & Oliver Kirchkamp & $\begin{array}{l}\text { Simultaneous Evolution of Learning Rules and } \\
\text { Strategies }\end{array}$ \\
\hline $98-45$ & $\begin{array}{l}\text { Martin Weber } \\
\text { Jan Pieter Krahnen } \\
\text { Frank Voßmann }\end{array}$ & $\begin{array}{l}\text { Risikomessung im Kreditgeschäft: Eine empirische } \\
\text { Analyse bankinterner Ratingverfahren }\end{array}$ \\
\hline $98-44$ & Axel Börsch-Supan & $\begin{array}{l}\text { Anreizprobleme in der Renten- und } \\
\text { Krankenversicherung }\end{array}$ \\
\hline $98-43$ & Martin Hellwig & $\begin{array}{l}\text { On the Economics and Politics of Corporate } \\
\text { Finance and Corporate Control }\end{array}$ \\
\hline $98-42$ & Axel Börsch-Supan & $\begin{array}{l}\text { Demographie, Entwicklung und Stabilität der } \\
\text { Sozialversicherung in Deutschland }\end{array}$ \\
\hline $98-41$ & Axel Börsch-Supan & $\begin{array}{l}\text { Zur deutschen Diskussion eines Übergangs vom } \\
\text { Umlage- zum Kapitaldeckungsverfahren in der } \\
\text { Gesetzlichen Rentenversicherung }\end{array}$ \\
\hline $98-40$ & Axel Börsch-Supan & $\begin{array}{l}\text { A Model under Siege: A Case Study of the } \\
\text { Germany Retirement Insurance System }\end{array}$ \\
\hline $98-39$ & Martin Hellwig & Financial Intermediation with Risk Aversion \\
\hline $98-38$ & Martin Hellwig & $\begin{array}{l}\text { Risk Aversion and Incentive Compatibility with Ex } \\
\text { Post Information Asymmetry }\end{array}$ \\
\hline $98-37$ & $\begin{array}{l}\text { Roman Inderst } \\
\text { Christian Pfeil }\end{array}$ & Duopolistic Competition in Search Markets \\
\hline $98-36$ & Roman Inderst & Incentives Schemes as a Signaling Device \\
\hline $98-35$ & Roman Inderst & Multi-Issue Bargaining with Endogenous Agenda \\
\hline $98-34$ & Roman Inderst & Competition Drives Up Prices \\
\hline
\end{tabular}




\begin{tabular}{|c|c|c|}
\hline Nr. & Author & Title \\
\hline $98-33$ & Roman Inderst & A Note on the Limited Value of Time for Screening \\
\hline $98-32$ & Roman Inderst & Screening With Endogenous Reservation Values \\
\hline $98-31$ & Paul Povel & optimal bankruptcy laws \\
\hline $98-30$ & Martin Hellwig & Systemische Risiken im Finanzsektor \\
\hline $98-29$ & Axel Börsch-Supan & $\begin{array}{l}\text { Incentive Effects of Social Security on Labor Force } \\
\text { Participation: Evidence in Germany and Across } \\
\text { Europe }\end{array}$ \\
\hline $98-22$ & $\begin{array}{l}\text { Phillipe Jehiel } \\
\text { Benny Moldovanu }\end{array}$ & Efficient Design with Interdependent Valuations \\
\hline $98-21$ & $\begin{array}{l}\text { Benny Moldovanu } \\
\text { Aner Sela }\end{array}$ & Patent Licensing to Bertrand Competitors \\
\hline $98-20$ & Alfred Kieser & $\begin{array}{l}\text { How Management Science, Consultancies and } \\
\text { Business Companies (Do not) Learn from Each } \\
\text { Other. Applying Concepts of Learning to Different } \\
\text { Types of Organizations and to Interorganizational } \\
\text { Learning }\end{array}$ \\
\hline $98-16$ & $\begin{array}{l}\text { Tilmann Betsch } \\
\text { Babette Brinkmann } \\
\text { Klaus Fiedler } \\
\text { Katja Breining }\end{array}$ & $\begin{array}{l}\text { When prior knowledge overrules new evidence: } \\
\text { Adaptive use of decision strategies and role } \\
\text { behavioral routines }\end{array}$ \\
\hline $98-15$ & Klaus Fiedler & $\begin{array}{l}\text { Illusory Correlations: Explicating and Stimulating } \\
\text { Their Apparent and Less Apparent Origins }\end{array}$ \\
\hline 98-14 & $\begin{array}{l}\text { Klaus Fiedler } \\
\text { Babette Brinkmann } \\
\text { Tilmann Betsch } \\
\text { Beate Wild }\end{array}$ & $\begin{array}{l}\text { A Sampling Approach to Biases in Conditional } \\
\text { Probability Judgments: Beyond Baserate-Neglect } \\
\text { and Statistical Format }\end{array}$ \\
\hline $98-13$ & $\begin{array}{l}\text { Tilmann Betsch } \\
\text { Stefan Krauss }\end{array}$ & $\begin{array}{l}\text { Eine Kritik an der klassischen Framing - Studie, } \\
\text { eine konzeptuelle Replikation und eine Bewertung } \\
\text { der Prospect Theory. }\end{array}$ \\
\hline
\end{tabular}

\begin{tabular}{|c|c|c|}
\hline Nr. & $\begin{array}{l}\text { Author } \\
\end{array}$ & "Title \\
\hline $98-12$ & $\begin{array}{l}\text { Siegfried K. Berninghaus } \\
\text { Karl-Martin Ehrhart } \\
\text { Claudia Keser }\end{array}$ & $\begin{array}{l}\text { Conventions and Local Interaction Structures: } \\
\text { Experimental Evidence }\end{array}$ \\
\hline $98-11$ & $\begin{array}{l}\text { Michael Kilka } \\
\text { Martin Weber }\end{array}$ & $\begin{array}{l}\text { What Determines the Shape of the Probability } \\
\text { Weighting Function under Uncertainty? }\end{array}$ \\
\hline $98-10$ & $\begin{array}{l}\text { Tilmann Betsch } \\
\text { Frank Siebler } \\
\text { Peter Marz } \\
\text { Stefan Hormuth } \\
\text { Dorothee Dickenberger }\end{array}$ & $\begin{array}{l}\text { The moderating role of category salience and } \\
\text { category focus in judgments of set size and } \\
\text { frequency of occurence. }\end{array}$ \\
\hline $98-08$ & Peter Albrecht & $\begin{array}{l}\text { Alterssicherung und Vorsorgebedarf im } \\
\text { Spannungsfeld von Versicherungs- und } \\
\text { Investmentprodukten }\end{array}$ \\
\hline $98-07$ & $\begin{array}{l}\text { Axel Börsch-Supan } \\
\text { Annette Reil-Held } \\
\text { Reinhold Schnabel }\end{array}$ & Pension Provision in Germany \\
\hline $98-06$ & $\begin{array}{l}\text { Martin Hellwig } \\
\text { Klaus M. Schmidt }\end{array}$ & $\begin{array}{l}\text { Discrete-Time Approximations of the } \\
\text { Holmström-Milgrom Brownian-Motion, Model of } \\
\text { Intertemporal Incentive Provision }\end{array}$ \\
\hline 98-05 & $\begin{array}{l}\text { Tilmann Betsch } \\
\text { G. - M. Biel } \\
\text { C. Eddelbuettel } \\
\text { A. Mock }\end{array}$ & Natural sampling and base-rate neglect \\
\hline $98-04$ & Martin Hellwig & $\begin{array}{l}\text { Allowing for Risk Choices in Diamond's "Financial } \\
\text { Intermediation as Delegated Monitoring" }\end{array}$ \\
\hline $98-03$ & $\begin{array}{l}\text { Martin Weber } \\
\text { Lukas Mangelsdorff }\end{array}$ & $\begin{array}{l}\text { Hindsight-Bias im Prinzipal-Agent-Kontext: Die } \\
\text { Aktennotiz als Antwort? }\end{array}$ \\
\hline 98-02 & $\begin{array}{l}\text { Alfred Kieser } \\
\text { Nikolaus Beck } \\
\text { Risto Tainio }\end{array}$ & $\begin{array}{l}\text { Limited Rationality, Formal Organizational Rules, } \\
\text { and Organizational Learning (OL) }\end{array}$ \\
\hline $98-01$ & Office SFB504 & Sonderforschungsbereich 504 Jahresbericht 1998 \\
\hline
\end{tabular}

SONDERFORSCHUNGSBereich 504 WORKING PAPER SERIES

\begin{tabular}{|c|c|c|}
\hline Nr. & Author & 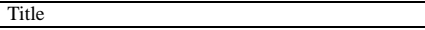 \\
\hline $97-44$ & $\begin{array}{l}\text { Raimond Maurer } \\
\text { Michael Adam }\end{array}$ & $\begin{array}{l}\text { Analytische Evaluation des Risiko-Chance-Profils } \\
\text { kombinierter Aktien- und Optionsstrategien }\end{array}$ \\
\hline $97-43$ & Holger M. Müller & The Mirrlees-Problem Revisited \\
\hline $97-42$ & Annette Reil-Held & $\begin{array}{l}\text { Bequests and Aggregate Wealth Accumulation in } \\
\text { Germany }\end{array}$ \\
\hline $97-41$ & Axel Börsch-Supan & $\begin{array}{l}\text { Übergangsmodelle vom Umlage - zum } \\
\text { Kapitaldeckungsverfahren in der deutschen } \\
\text { Rentenversicherung }\end{array}$ \\
\hline $97-40$ & $\begin{array}{l}\text { Siegfried K. Berninghaus } \\
\text { Karl-Martin Ehrhart } \\
\text { Claudia Keser }\end{array}$ & $\begin{array}{l}\text { The invisible hand: Experiments on strategy } \\
\text { selection in population games }\end{array}$ \\
\hline $97-39$ & $\begin{array}{l}\text { Axel Börsch-Supan } \\
\text { Annette Reil-Held }\end{array}$ & $\begin{array}{l}\text { Retirement Income: Level, Risk, and Substitution } \\
\text { Among Income Components }\end{array}$ \\
\hline $97-38$ & Holger M. Müller & $\begin{array}{l}\text { The First-Best Sharing Rule in the } \\
\text { Continuous-Time Principal-Agent Problem with } \\
\text { Exponential Utility }\end{array}$ \\
\hline $97-37$ & Holger M. Müller & $\begin{array}{l}\text { Randomization in Dynamic Principal-Agent } \\
\text { Problems }\end{array}$ \\
\hline $97-36$ & $\begin{array}{l}\text { Gyöngyi Bugàr } \\
\text { Raimond Maurer }\end{array}$ & $\begin{array}{l}\text { International Portfolio Diversification for European } \\
\text { countries: The viewpoint of Hungarian and German } \\
\text { investors }\end{array}$ \\
\hline $97-35$ & Martin Hellwig & $\begin{array}{l}\text { Banks, Markets, and the Allocation of Risks in an } \\
\text { Economy }\end{array}$ \\
\hline $97-34$ & $\begin{array}{l}\text { Nikolaus Beck } \\
\text { Alfred Kieser }\end{array}$ & $\begin{array}{l}\text { Standard Operating Procedures and Organizational } \\
\text { Learning }\end{array}$ \\
\hline $97-33$ & $\begin{array}{l}\text { Thomas Langer } \\
\text { Peter Waller }\end{array}$ & $\begin{array}{l}\text { Implementing Behavioral Concepts into Banking } \\
\text { Theory: The Impact of Loss Aversion on } \\
\text { Collateralization }\end{array}$ \\
\hline $97-32$ & $\begin{array}{l}\text { Guenther Franke } \\
\text { Martin Weber }\end{array}$ & Risk-Value Efficient Portfolios and Asset Pricing \\
\hline
\end{tabular}

SONDERFORSCHUNGSBereich 504 WORKING PAPER SERIES

\begin{tabular}{|c|c|c|}
\hline Nr. & $\begin{array}{l}\text { Author } \\
\end{array}$ & 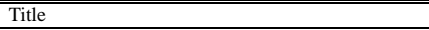 \\
\hline $97-31$ & Axel Börsch-Supan & $\begin{array}{l}\text { Das deutsche Rentenversicherungssystem: } \\
\text { Probleme und Perspektiven }\end{array}$ \\
\hline $97-30$ & $\begin{array}{l}\text { Claudia Keser } \\
\text { Marc Willinger }\end{array}$ & Principals \\
\hline $97-29$ & $\begin{array}{l}\text { Siegfried K. Berninghaus } \\
\text { Karl-Martin Ehrhart } \\
\text { Claudia Keser }\end{array}$ & Coordination Games: Recent Experimental Results \\
\hline $97-28$ & Peter Albrecht & $\begin{array}{l}\text { A Stochastic Approach for the Quantification of } \\
\text { Default Risk of OTC-Financial Derivatives }\end{array}$ \\
\hline $97-27$ & $\begin{array}{l}\text { Dagmar Stahlberg } \\
\text { A. Maass }\end{array}$ & $\begin{array}{l}\text { Hindsight bias: Impaired memory or biased } \\
\text { reconstruction? }\end{array}$ \\
\hline $97-26$ & $\begin{array}{l}\text { Manfred Hassebrauck } \\
\text { Cornelia Vogt } \\
\text { Michael Diehl }\end{array}$ & $\begin{array}{l}\text { Das "prototype matching"-Modell des } \\
\text { Entscheidungsverhaltens: Darstellung des Modells } \\
\text { und erste Ergebnisse }\end{array}$ \\
\hline $97-24$ & Claudia Keser & $\begin{array}{l}\text { SUPER: Strategies used in public goods } \\
\text { experimentation rounds }\end{array}$ \\
\hline $97-23$ & Axel Börsch-Supan & $\begin{array}{l}\text { Germany: A social security system on the verge of } \\
\text { collaps }\end{array}$ \\
\hline $97-22$ & Axel Börsch-Supan & $\begin{array}{l}\text { Privatisierungsmöglichkeiten der } \\
\text { Sozialversicherung in Europa }\end{array}$ \\
\hline $97-21$ & Axel Börsch-Supan & Capital productivity and the nature of competition \\
\hline $97-20$ & $\begin{array}{l}\text { Axel Börsch-Supan } \\
\text { Reinhold Schnabel }\end{array}$ & Social security and retirement in germany \\
\hline $97-19$ & Raimond Maurer & $\begin{array}{l}\text { Ertrag und Shortfall Risiko von } \\
\text { Wertsicherungsstrategien mit Optionen unter } \\
\text { alternativen Zielrenditen: Empirische Evidenzen für } \\
\text { den deutschen Aktienmarkt }\end{array}$ \\
\hline $97-18$ & Peter Albrecht & $\begin{array}{l}\text { Risk based capital allocation and risk adjusted } \\
\text { performance management in } \\
\text { property/liability-insurance: A risk theoretical } \\
\text { framework }\end{array}$ \\
\hline
\end{tabular}




\begin{tabular}{|c|c|c|}
\hline Nr. & Author & 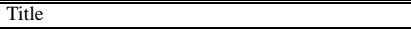 \\
\hline $97-17$ & $\begin{array}{l}\text { Peter Albrecht } \\
\text { Raimond Maurer } \\
\text { Matthias Möller }\end{array}$ & $\begin{array}{l}\text { Shortfall-Risiko/Excess-Chance- } \\
\text { Entscheidungskalküle: Grundlagen und } \\
\text { Beziehungen zum Bernoulli-Prinzip }\end{array}$ \\
\hline $97-16$ & $\begin{array}{l}\text { Claudia Keser } \\
\text { Karl-Martin Ehrhart } \\
\text { Siegfried K. Berninghaus }\end{array}$ & $\begin{array}{l}\text { Coordination and local interaction: Experimental } \\
\text { evidence }\end{array}$ \\
\hline $97-15$ & $\begin{array}{l}\text { Herbert Bless } \\
\text { Tilmann Betsch } \\
\text { Axel Franzen }\end{array}$ & $\begin{array}{l}\text { Framing the framing effect: The impact of context } \\
\text { cues on solutions to the "asian disease" problem }\end{array}$ \\
\hline $97-14$ & $\begin{array}{l}\text { Michael Kilka } \\
\text { Martin Weber }\end{array}$ & $\begin{array}{l}\text { Home Bias in International Stock Return } \\
\text { Expectation }\end{array}$ \\
\hline $97-13$ & Jan Vleugels & $\begin{array}{l}\text { Bidding against an unknown number of } \\
\text { competitiors sharing affiliated information }\end{array}$ \\
\hline $97-12$ & $\begin{array}{l}\text { Dov Monderer } \\
\text { Aner Sela }\end{array}$ & Fictitious play and- no-cycling conditions \\
\hline $97-11$ & $\begin{array}{l}\text { S. Hon-Suir } \\
\text { Dov Monderer } \\
\text { Aner Sela }\end{array}$ & A learning approach to auctions \\
\hline $97-10$ & $\begin{array}{l}\text { Karl H. Schlag } \\
\text { Aner Sela }\end{array}$ & You play (an auction) only once \\
\hline 97-09 & Aner Sela & One against all in the fictitious play process \\
\hline $97-08$ & Benny Moldovanu & $\begin{array}{l}\text { William Vickrey und die Auktionstheorie - } \\
\text { Anmerkungen zum Nobelpreis } 1996\end{array}$ \\
\hline 97-07 & $\begin{array}{l}\text { M. Tietzel } \\
\text { Benny Moldovanu }\end{array}$ & Goethe \\
\hline $97-06$ & $\begin{array}{l}\text { Phillipe Jehiel } \\
\text { Benny Moldovanu }\end{array}$ & $\begin{array}{l}\text { Auctions with Downstream Interaction among } \\
\text { Buyers }\end{array}$ \\
\hline $97-05$ & $\begin{array}{l}\text { Phillipe Jehiel } \\
\text { Benny Moldovanu }\end{array}$ & $\begin{array}{l}\text { Resale Markets and the Assignment of Property } \\
\text { Rights }\end{array}$ \\
\hline
\end{tabular}

SONDERFORSCHUNGSBereich 504 WORKING PAPER SERIES

\begin{tabular}{|c|c|c|}
\hline Nr. & "Author & $\begin{array}{ll}\text { Title } \\
\end{array}$ \\
\hline 97-04 & $\begin{array}{l}\text { Phillipe Jehiel } \\
\text { Benny Moldovanu } \\
\text { E. Stacchetti }\end{array}$ & $\begin{array}{l}\text { Multidimensional Mechanism Design for Auctions } \\
\text { with Externalities }\end{array}$ \\
\hline $97-03$ & Karsten Fieseler & $\begin{array}{l}\text { Bidding for unit-price contracts - How craftsmen } \\
\text { should bid }\end{array}$ \\
\hline 97-02 & Martin Hellwig & $\begin{array}{l}\text { Unternehmensfinanzierung, Unternehmenskontrolle } \\
\text { und Ressourcenallokation: Was leistet das } \\
\text { Finanzsystem? }\end{array}$ \\
\hline \multirow[t]{4}{*}{ 97-01 } & Ralf Rodepeter & Identifikation von Sparprofilen im Lebenszyklus \\
\hline & Daniel Schunk & $\begin{array}{l}\text { The Pennsylvania Reemployment Bonus } \\
\text { Experiments: How a survival model helps in the } \\
\text { analysis of the data }\end{array}$ \\
\hline & Volker Stocké & $\begin{array}{l}\text { Measuring Information Accessibility and Predicting } \\
\text { Response-Effects: The Validity of } \\
\text { Response-Certainties and Response-Latencies }\end{array}$ \\
\hline & $\begin{array}{l}\text { Volker Stocké } \\
\text { Bettina Langfeldt }\end{array}$ & $\begin{array}{l}\text { Umfrageeinstellung und Umfrageerfahrung. Die } \\
\text { relative Bedeutung unterschiedlicher Aspekte der } \\
\text { Interviewerfahrung für die generalisierte } \\
\text { Umfrageeinstellung }\end{array}$ \\
\hline
\end{tabular}

